\title{
Sociotechnical system studies of the reduction of greenhouse gas emissions from energy and transport systems
}

\author{
Linda Olsson
}

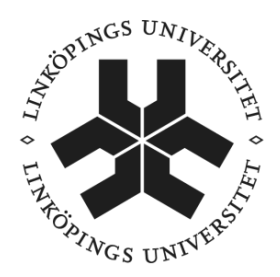

\section{Linköping University INSTITUTE OF TECHNOLOGY}

Department of Management and Engineering Linköping University, Sweden Linköping, May 2015 
Sociotechnical system studies of the reduction of greenhouse gas emissions from energy and transport systems

CLinda Olsson, 2015

Cover design: Per Lagman/LiU-Tryck

Printed in Sweden by LiU-Tryck, Linköping, Sweden, 2015

ISBN: 978-91-7519-082-2

ISSN: 0345-7524 
This thesis is based on work conducted within the interdisciplinary graduate school Energy Systems. The national Energy Systems Programme aims at creating competence in solving complex energy problems by combining technical and social sciences. The research programme analyses processes for the conversion, transmission and utilisation of energy, combined together in order to fulfil specific needs.

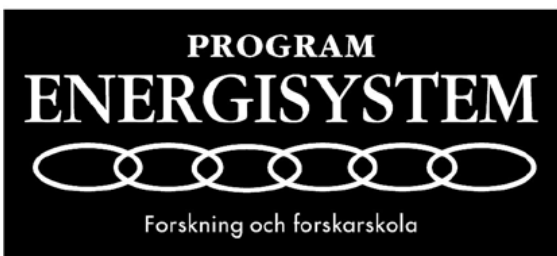

The research groups that constitute the Energy Systems Programme are the Department of Engineering Sciences at Uppsala University, the Division of Energy Systems at Linköping Institute of Technology, the Research Theme Technology and Social Change at Linköping University, the Division of Heat and Power Technology at Chalmers University of Technology in Göteborg as well as the Division of Energy Processes at the Royal Institute of Technology in Stockholm. Associated research groups are the Division of Environmental Systems Analysis at Chalmers University of Technology in Göteborg as well as the Division of Electric Power Systems at the Royal Institute of Technology in Stockholm.

www.liu.se/energi 



\section{Abstract}

It is agreed that greenhouse gas (GHG) emissions from energy and transport systems must be reduced. Technical means exist to reduce GHG emissions from these sources. However, these emission-reduction measures are not implemented to a high enough degree. In this thesis, it is assumed that this is because the reduction of GHG emissions from energy and transport systems is a wicked problem. Unlike a tame problem, which has an unambiguous definition and a finite number of welldefined solutions, a wicked problem is difficult to define, and its solutions are often intertwined with the problem. The "wickedness" of a wicked problem lies in the extreme difficulty of solving the problem, rather than in the problem itself.

In this thesis, the wicked problem of reducing GHG emissions from energy and transport systems is studied by applying a sociotechnical systems approach to the introduction of renewable vehicle fuels, the production and use of biogas, the introduction of electric vehicles, and the sustainability of district heating. In addition, this thesis discusses how energy issues are approached in different contexts, and what implications different actions can have on GHG emissions.

The analysis shows that a sociotechnical approach to energy systems analysis can offer insights with regard to how system boundaries are handled within GHGemission assessments and energy and transport policy. By problematising the use of system boundaries in GHG-emission assessments, this thesis explains how attempts to reduce GHG emissions could add to the wicked problem of GHG-emission reductions from energy and transport systems. GHG-emission assessments can give very different results depending on system boundaries. While these results can be used in attempts to solve this wicked problem, they can also contribute to complicating it. As solutions to wicked problems are mainly found in policy, the use of system boundaries in policy is studied. Results show that narrow system boundaries in energy and transport policy can hamper sustainable development of energy and transport systems. The use of wider system boundaries could facilitate approaches to solve the wicked problem of reducing GHG emissions from energy and transport systems by making the consequences and effects of policy actions more clearly visible. 


\section{Sammanfattning}

Det är välkänt att energi- och transportsystemens utsläpp av växthusgaser måste minska. Tekniska förutsättningar för att minska utsläppen av växthusgaser från användning av energi och transporter existerar. Ändå genomförs inte åtgärder för att minska utsläpp av växthusgaser i tillräcklig utsträckning. I föreliggande avhandling antas detta bero på att minskandet av utsläpp av växthusgaser från energi- och transportsystem är ett 'wicked problem'. Ett sådant problem är svårdefinierat och motståndskraftigt mot lösningar, eftersom lösningarna ofta är sammanflätade med problemet.

I avhandlingen studeras frågan om hur utsläpp av växthusgaser från energi- och transportsystem kan minska. Introduktion av förnybara drivmedel, produktion och användning av biogas, introduktion av elbilar, samt hållbarhet i fjärrvärmesystem är områden som studeras med hjälp av ett sociotekniskt angreppssätt. Detta innebär att teknik studeras som en integrerad del av samhället, där teknik både påverkar och påverkas av aktörer och sociala strukturer.

Analysen visar att ett sociotekniskt angreppssätt kan ge insikter om hur systemgränser hanteras inom energisystemforskning samt inom energi- och transportpolicy. Värderingar av växthusgasutsläpp, som utförs inom energisystemforskning, kan ge vitt skilda resultat beroende på hur det studerade systemet avgränsats. Resultaten kan användas i försök att minska utsläpp av växthusgaser från energi- och transportsystem, men detta kan leda till att problemet försvåras ytterligare. I avhandlingen förklaras detta genom problematisering av systemavgränsningar i värderingar av växthusgasutsläpp. Eftersom lösningar på 'wicked problems' oftast återfinns inom policy, studeras även systemavgränsningar i policy. Det visas att snäva systemgränser inom energi- och transportpolicy kan hindra hållbar utveckling av energi- och transportsystem. Vidgade systemgränser skulle kunna underlätta ansatser att minska utsläpp av växthusgaser från energi- och transportsystem genom att synliggöra konsekvenser och effekter av policyåtgärder. 


\section{List of appended papers and co-author statement}

I. Bridging the implementation gap: Combining backcasting and policy analysis to study renewable energy in urban road transport.

Linda Olsson, Linnea Hjalmarsson, Martina Wikström and Mårten Larsson. Transport Policy 37:72-82, 2015.

II. Policy for biomass utilisation in energy and transport systems - the case of biogas in Stockholm, Sweden.

Linda Olsson and Linnea Hjalmarsson.

In Proceedings from World Renewable Energy Forum 2012, May 13-17

2012, Denver, Colorado, USA.

III. Waste(d) potential: A socio-technical analysis of biogas production and use in Sweden.

Linda Olsson and Magdalena Fallde.

Journal of Cleaner Production, In Press.

IV. Climate impact of the electrification of road transport in a short-term perspective.

Linda Olsson and Annelie Carlson.

In Proceedings from World Conference on Transport Research 2013, July

15-18 2013, Rio de Janeiro, Brazil.

$\mathrm{V}$. The role of electric vehicles in EU energy and transport policy.

Linda Olsson, Annelie Carlson and Magdalena Fallde.

Submitted to a journal.

VI. Assessing the climate impact of district heating systems with combined heat and power production and industrial excess heat.

Linda Olsson, Elisabeth Wetterlund and Mats Söderström.

Resources, Conservation and Recycling 96:31-39, 2015.

I was the main author of paper I, in collaboration with Linnea Eriksson (née Hjalmarsson) and Martina Wikström. Data collection was performed by Linnea Eriksson, Mårten Larsson and Martina Wikström. The work was supervised by Professor Jenny Palm, Associate Professor Mats Söderström, Dr Magdalena Fallde, Dr Elisabeth Wetterlund and Dr Lisa Hansson. 
Linnea Eriksson and I contributed equally to writing paper II. For data collection, I handled technical data and Linnea Eriksson performed interviews. The work was supervised by Professor Jenny Palm and Associate Professor Louise Trygg.

I was the main author of papers III-VI, and I was solely responsible for collecting data for these papers. My supervisors contributed with valuable insights regarding analysis and discussion. Dr Magdalena Fallde supervised the work in papers III and V, Dr Annelie Carlson supervised the work in papers IV and V, and Dr Elisabeth Wetterlund and Associate Professor Mats Söderström supervised the work in paper VI. 


\section{Acknowledgements}

This thesis is written within the Energy Systems Programme, an interdisciplinary postgraduate school financed by the Swedish Energy Agency. Being part of this programme has widened my view of the world and given me the opportunity to meet amazing people, and for that I am very grateful.

Above all, I want to thank my supervisor Mats Söderström for never-ending encouragement and support, my fabulous co-supervisors Annelie Carlson, Magdalena Fallde and Elisabeth Wetterlund for great discussions and constructive criticism, and my initial supervisor Louise Trygg for introducing me to the subject of local energy systems. I also want to thank my co-authors Linnea Eriksson, Mårten Larsson and Martina Wikström for excellent co-operation and lots of fun when taking a break from work. I sincerely thank Stefan Anderberg for reading my thesis incredibly thoroughly and sharing his comments with me at a seminar.

My colleagues at the division of Energy Systems and in the Energy Systems Programme have brightened the days at work. I particularly want to thank Sandra Backlund, Sarah Broberg Viklund and Klas Svensson for hilarious coffee-breaks and support in the PhD student process, and the members of PES D10 for great times endless hours of discussing interdisciplinary texts, punctuated by eating cake. I also want to thank Elisabeth Larsson for knowing and fixing everything administrative (and probably ordering the cake).

I want to thank Sarah Darby and her colleagues at the Environmental Change Institute, University of Oxford, for letting me spend a few weeks with them, discussing research and working on my thesis. I also want to thank Tina Erlandsson, Amie Fallqvist, Sofia Göth and Johan Hedbrant for influencing my PhD studies through recurring discussions about research and academia over coffee.

Last but not least, I am grateful for my family and friends, who have very little to do with the content of this thesis but mean the world to me. I want to specifically mention my canine companion, who is a constant source of tail-wagging joy, and my awesome skydiving car-fixing iron man Jonas. You make me a better person. 


\section{Contents}

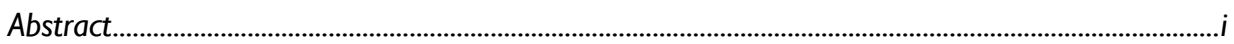

Sammanfattning ..........................................................................................................................ii

List of appended papers and co-author statement .............................................................................

Acknowledgements ............................................................................................................................... vii

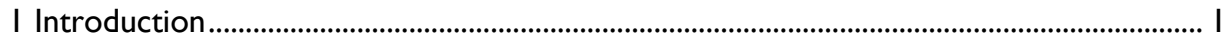

I.I Aim and research questions ........................................................................................... 3

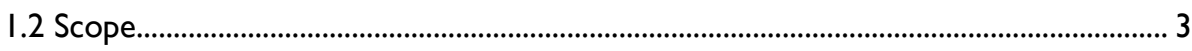

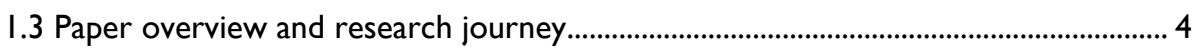

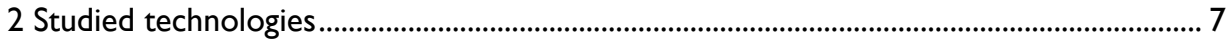

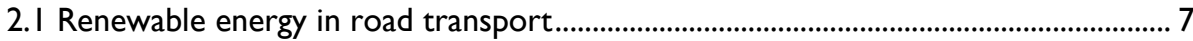

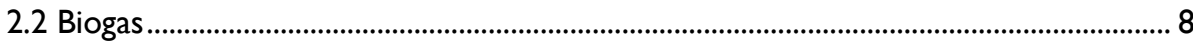

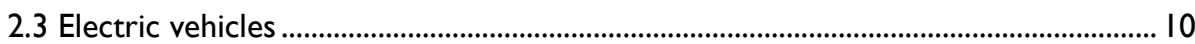

2.4 District heating with CHP production and industrial excess heat............................ I I

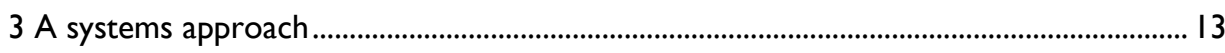

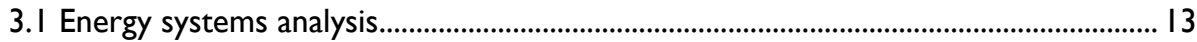

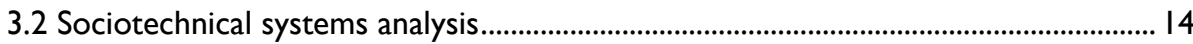

4 Methodology and material................................................................................................. 17

4.I Greenhouse gas emission assessments .................................................................... 17

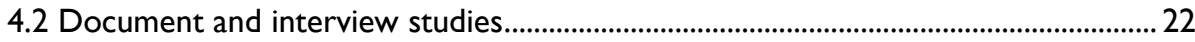

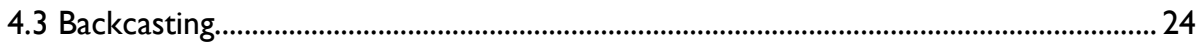

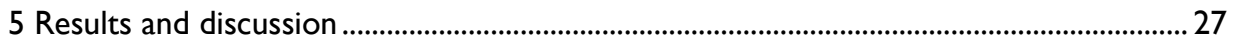

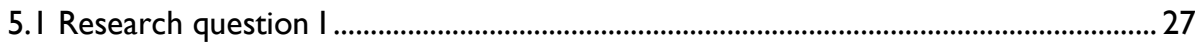

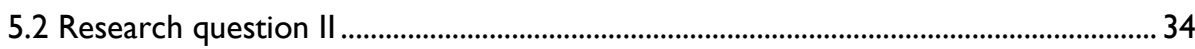

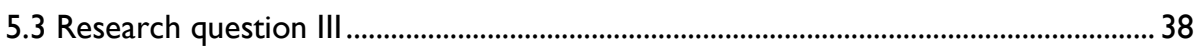

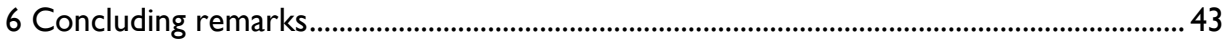

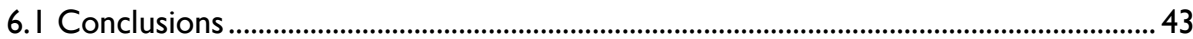

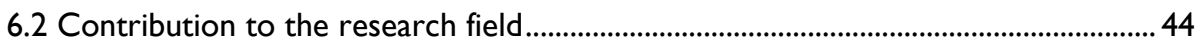

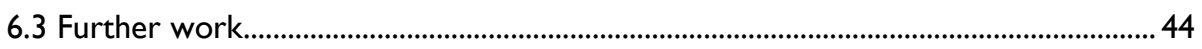

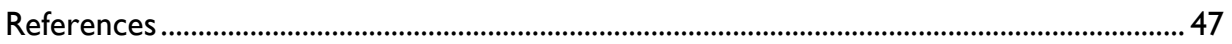




\section{Introduction}

The sustainable development of energy and transport systems is a topic that is often addressed in research, policy and media. Problems are discussed, solutions are suggested and policy is created. The definition of 'sustainable development' is debated (Holden et al., 2014), and depending on their backgrounds stakeholders can have many different ideas about what sustainable development means and how it can be achieved. The point of departure for this thesis is that current energy use is a major source of anthropogenic climate change, through the emissions of greenhouse gases (GHG), and that measures to achieve GHG-emission reductions are not yet implemented to a degree high enough to successfully mitigate climate change (IPCC, 2014). The reduction of GHG emissions is considered to be one of the major means of achieving sustainable development in energy and transport systems, and is the focus of this thesis. Sustainable development is a term that encompasses several ecological, economic and social factors, but here, sustainability is considered only in an ecological sense and with regard to GHG emissions.

In 1973, Rittel and Webber formulated a theory of wicked problems. They claimed that while the science community had learned how to solve tame problems (such as equations and chemical analyses), the truly complex social problems (such as social justice and global climate change) remained unsolved. Some of the characteristics of a wicked problem are that it is not unequivocally definable, it does not have an enumerable set of potential solutions, and its solutions cannot be defined as 'true or false' but are rather defined as 'good or bad' (Rittel and Webber, 1973). The problem and its solutions are intertwined, and just as the problem determines its solution, the solutions also affect the problem. Thus, the wickedness can be said to lie in solving the problem rather than in the problem itself. 
Energy issues have been described as wicked problems in previous research. Chester (2010) likens energy security to a wicked problem. She calls energy security a 'slippery' term that may be defined differently depending on which country, energy source and time-frame is being considered. She argues that although the concept should be brought to discussion, a rigid definition would not be useful. Instead, she states that it is "establishe[d] that there can be no one-size-fits-all solution" and that the challenges posed by energy security "require new ways of thinking" (Chester, 2010: p. 893). Fast and McCormick (2012) present an exhaustive analysis of how biofuels can be considered a wicked problem. Although biofuels are part of the solution toward mitigating climate change, they may also become part of the problem. Great uncertainty exists as to the environmental benefits of biofuel production, and several social and environmental problems could arise from its use. 'Traditional' science offers solutions to some of these problems, but for others the authors suggest that research should be expanded and "enrol more perspectives and more knowledge types" (Fast and McCormick, 2012: p. 745).

In this thesis, the reduction of GHG emissions from energy and transport systems is considered to be a wicked problem. What constitutes a GHG-emission reduction is not unambiguous, as will be shown in this thesis. Solutions to the problem include a reduction of energy use and a fundamental change of energy supply, neither of which seems highly desirable among world leaders; thus, these solutions can be labelled both 'good', as they can help to mitigate climate change, and 'bad', as they are unwanted. To further complicate the issue, the energy use that has led to climate change has also led to technological progress, economic growth and increased quality of life. There are not only problems, but also great opportunities associated with energy use. Studying the reduction of GHG emissions from energy and transport systems as a wicked problem allows for problematising solutions and measures to reduce GHG emissions. This approach can contribute to our understanding of why climate change mitigation seems so difficult to achieve despite all the available knowledge and technology.

The call for additional perspectives and knowledge types to understand wicked problems is the foundation of this thesis. Here, the reduction of GHG emissions from energy and transport systems is studied with different perspectives and methods in a sociotechnical systems approach. The appended papers investigate how energy issues are approached in different contexts, and what implications different actions can have on GHG emissions. System boundaries are studied in all the appended papers. The choice of system boundaries shows how problems are approached and how solutions are created. As a wicked problem can be defined through attempts to find 
solutions, system boundaries can also provide insights into how the wicked problem that is the subject of this thesis is defined. The study of system boundaries is thus important for understanding GHG emission reductions from energy and transport systems as a wicked problem.

Several of these papers concern transport, which is a major source of GHG emissions because of its high use of fossil fuels. The energy use in transport can be considered part of a larger energy system, but transport is often regarded as a system itself, separate from the energy system. Therefore, I will refer to "energy use in the transport system" and also to "transport as an energy user in the energy system" in the thesis, depending on the context.

\section{I.I Aim and research questions}

The aim of this thesis is to show how the reduction of GHG emissions from energy and transport systems can be understood, approached and studied as a wicked problem. This aim is concretised in three research questions:

Research question I: How does the choice of system boundaries affect the results of energy system research?

Research question II: How do the system boundaries used in energy and transport policy affect the sustainable development of energy and transport systems?

Research question III: How can a sociotechnical systems approach benefit studies of GHG-emission reductions from energy and transport systems?

Table 1 shows which research questions that are addressed in which of the appended papers.

Table I. The relationships between papers and research questions (RQs).

\begin{tabular}{lcccccc} 
& Paper I & Paper II & Paper III & Paper IV & Paper V & Paper VI \\
\hline RQ I & & $\mathbf{x}$ & & $\mathbf{x}$ & & $\mathbf{x}$ \\
\hline RQ II & $\mathbf{x}$ & $\mathbf{x}$ & $\mathbf{x}$ & & $\mathbf{x}$ & \\
\hline RQ III & $\mathbf{x}$ & $\mathbf{x}$ & $\mathbf{x}$ & $\mathbf{x}$ & $\mathbf{x}$ & $\mathbf{x}$ \\
\hline
\end{tabular}

\section{I.2 Scope}

This thesis is based on papers that concern the use of renewable fuels and energyefficient vehicles in road transport, with particular focus on biogas and electric vehicles, and district heating. As the high GHG emissions of transport are generally understood to be difficult to reduce, research into alternative transport technologies is needed. District heating is a complicated case in terms of GHG emissions as it in- 
cludes and interacts with several technologies. Thus, it is interesting to study with regard to the aim of this thesis.

Geographic system boundaries vary between Stockholm, Sweden and the European Union (EU). Sustainable development and climate change mitigation are important issues in the Swedish political agenda, wherefore Sweden and Stockholm are interesting to study. Biogas and district heating are established technologies in Sweden, and electric vehicles are viewed as a future alternative with great potential. When studying electric vehicles, a European perspective is assumed, as the electricity use of these vehicles affects the electricity system, which is connected throughout Europe. Table 2 presents the distribution of system boundaries in the appended papers.

Table 2. Overview of system boundaries in the appended papers.

\begin{tabular}{lcc} 
& Geographic system boundary & Technology \\
\hline Paper I & Local/regional & Biofuels \& electric vehicles \\
\hline Paper II & Local/regional & Biogas \\
\hline Paper III & National & Biogas \\
\hline Paper IV & European & Electric vehicles \\
\hline Paper V & European & Electric vehicles \\
\hline Paper VI & Local/regional \& European & District heating \\
\hline
\end{tabular}

\section{I.3 Paper overview and research journey}

My first year as a PhD student was spent doing coursework within an interdisciplinary research school: the Energy Systems Programme. In one of these courses, I collaborated with three other PhD students, Linnea Eriksson, Mårten Larsson and Martina Wikström, in an interdisciplinary project concerning renewable energy use in Stockholm's road transport system - the so-called tvärprojekt. The idea for the project came from a political vision of Stockholm as home to a large number of electric vehicles. With this as our starting point, we studied the conditions through which Stockholm's road transport could be entirely based on renewable energy by 2030.

Paper I: Bridging the implementation gap: Combining backcasting and policy analysis to study renewable energy in urban road transport

In paper I, which is a direct outcome of the tvärprojekt, the focus is on the discrepancy between Stockholm's policy makers' visions of a sustainable future transport system and the ongoing work required to get there. By combining backcasting and policy integration analysis, a gap between research results and the implementation of results in policy is identified. An interdisciplinary approach is shown to be suitable for attempts to reduce this gap. 
Stockholm's policy-makers were found to be particularly interested in biogas and electric vehicles. I found their interest notable, and focussed my research on the roles of biogas and electric vehicles as means to reduce GHG emissions from energy and transport systems. With biogas, I particularly wanted to understand the development of biogas production and the political interest in using biogas as a vehicle fuel. I found plentiful research on the potential of biogas, but limited literature explaining how the technology has developed. Therefore, the next two papers deal with this knowledge gap.

Paper II: Policy for biomass utilisation in energy and transport systems - the case of biogas in Stockholm, Sweden

This paper explores what made biogas such an attractive choice for Stockholm's policy-makers, and whether it was a good choice from a GHG-emissions point of view. The paper concludes that using biogas was not, in fact, the best choice for reducing GHG emissions, as electricity production could have reduced emissions more, given the chosen system boundaries. Another conclusion is that the choice to use biogas as vehicle fuel was driven by powerful actors involved in the policy process, who recognised opportunities to turn troublesome municipal waste into an environmentally beneficial and profitable solution for public transport.

Paper III: Waste(d) potential: A socio-technical analysis of biogas production and use in Sweden

Paper III was written to fill the knowledge gap of how Swedish biogas production has developed. One of the findings is that there is no apparent connection between research, policy and biogas production. Most of Sweden's biogas production started as a way of waste management, before biogas became very interesting in itself. With recent policy attention on using biogas as a vehicle fuel, the waste management aspect of biogas has become less interesting in the political arena, and biogas production is increasing slowly. The paper concludes that biogas production would benefit from political recognition of the diversity of biogas systems, and that all such systems should be targeted by policy.

Electric vehicles were a hot discussion topic during my time as a PhD student. Most people had a highly positive opinion about electric vehicles. For example, in the tvärprojekt, we found that electric vehicles were considered to be a vital part of a sustainable future road-transport system in Stockholm. Electric vehicles were said to improve the transport system by reducing GHG emissions, traffic noise and local air pollution. Usually, no potentially negative side-effects were mentioned. This positivity motivated me to study electric vehicles with regard to their contribution to GHGemission reductions, and how these vehicles are handled in policy. 


\section{Chapter I}

Paper IV: Climate impact of the electrification of road transport in a short-term perspective Electric vehicles are often promoted as zero GHG emitters, not only in the media but also in scientific literature. When their electricity use is mentioned, renewable electricity generation is generally assumed. However, this assumption does not coincide with the current energy situation. Paper IV was written in order to analyse energy use and GHG emissions from the use of electric vehicles given current European electricity production. The results show that in a life-cycle perspective, electric vehicles may currently contribute as much to climate change as fossil-fuelled cars. Acknowledging this fact could be a powerful incentive to increase renewable electricity generation.

Paper V: The role of electric vehicles in EU energy and transport policy

Paper $\mathrm{V}$ explores what problems electric vehicles are supposed to solve, according to EU policy. Electric vehicles are found to be viewed as instruments to maintain the current road transport system with respect to mobility and economic competitiveness, while still meeting climate goals. However, as policy fails to include the use and users of the vehicle, there is a risk that the encouragement of electric vehicles may not have a positive effect on climate change after all. To truly reduce GHG emissions from transport, structural changes in travelling and energy use are required.

A couple of years into my $\mathrm{PhD}$ studies, I was involved in a project concerning the allocation of GHG emissions from combined heat and power (CHP) production. As I had previously written papers in which GHG emissions from biogas use and electric vehicles were estimated, I was interested in the implications of using different methodological approaches when assessing GHG emissions. With this project, I was able to delve deeper into this issue, resulting in a paper that exemplifies and discusses the use of different methodological approaches to GHG-emission assessments.

Paper VI: Assessing the climate impact of district heating systems with combined heat and power production and industrial excess heat

In paper VI, the choice of system boundaries, input data and methodology is studied with regard to district heating. GHG-emission assessments for a district heating system with CHP production and/or industrial excess heat are analysed and discussed. The paper concludes that results differ depending on which methods and system boundaries are applied, and that it may be advantageous to use a local perspective. Paper VI concerns a different technology than the other papers, but the discussion of system perspectives is nonetheless similar. 


\section{Studied technologies}

In this chapter, the technical background of the thesis is presented. The technologies that are studied in the appended papers are described, with focus on their context in the papers and in the thesis. Thus, the relevance of a sociotechnical approach is further explained and motivated.

\section{I Renewable energy use in road transport}

Paper I examines the possibilities for exclusively using renewable energy in road transport by 2030. Although several renewable fuels could be considered, only a few were selected in paper I. This selection was based on a literature study with the aim of identifying the most likely renewable fuels for use in Sweden by 2030. Table 3 presents the renewable energy carriers that were selected and their main production pathway and use.

Table 3. Fuels deemed possible in Stockholm's road transport system in 2030.

\begin{tabular}{lll} 
Energy carrier & Main use in vehicles & Main production process \\
\hline $\begin{array}{l}\text { Biogas \& synthetic } \\
\text { natural gas (SNG) }\end{array}$ & $\begin{array}{l}\text { Public transport } \\
\text { Goods transport }\end{array}$ & $\begin{array}{l}\text { Anaerobic digestion of biomass (biogas) or } \\
\text { gasification of woody biomass (SNG) }\end{array}$ \\
\hline Ethanol & Automobiles & Fermentation of biomass \\
\hline $\begin{array}{l}\text { Biodiesel \& } \\
\text { synthetic diesel }\end{array}$ & $\begin{array}{l}\text { Automobiles } \\
\text { Goods transport }\end{array}$ & $\begin{array}{l}\text { Transesterification of fatty biomass (biodiesel) } \\
\text { or gasification of woody biomass (synthetic } \\
\text { diesel) }\end{array}$ \\
\hline Dimethyl ether (DME) & Goods transport & Gasification of woody biomass \\
\hline Electricity & Automobiles & $\begin{array}{l}\text { Solar, wind, hydro and tidal power, and } \\
\text { combustion of biomass }\end{array}$ \\
\hline
\end{tabular}

Research has shown that the use of biofuels such as those listed in Table 3 could reduce GHG emissions from transport (see for example Difs et al., 2010; Mohseni et al., 2012; Wetterlund et al., 2010). Great potential has also been identified in the amount of renewable energy that could be used in the transport sector. For example, 


\section{Chapter 2}

Lindfeldt et al. (2010) found that biofuels and renewably produced electricity could meet the energy demands of Swedish transport by 2025. However, biofuels and electric vehicles are currently not in common use. Despite attention from policy-makers and media, electric-vehicle uptake is slow in Stockholm (Nykvist and Nilsson, 2014). Ethanol and biodiesel are mainly used for blending with petrol and diesel, and biogas is used in private and public transport on a fairly small scale. In 2012, renewable fuels constituted $8 \%$ of the total energy use in the Swedish transport sector (SEA, 2014). Vehicle fuel production based on gasification of biomass is not yet done on a commercial scale, so the fuels resulting from that technology are not widely available. Hence, realisation of the opportunities identified by research is not imminent.

Other difficulties affect the implementation of biofuels, such as the debate over their sustainability. Although biofuels are assumed to reduce GHG emissions since they are based on renewable resources, research has shown that cultivation and production processes can be both socially and environmentally unsustainable, and that GHG emissions in some cases can increase (Börjesson, 2009; Ekener-Petersen et al., 2014; Fargione et al., 2008; Searchinger et al., 2008). Previously described as a wicked problem (Fast and McCormick, 2012), biofuels should be studied using several methods and perspectives.

\subsection{Biogas}

Papers II and III concern different aspects of biogas production and use. In paper II, options for using municipal organic waste in the Stockholm region are studied. In paper III, biogas production and use in Sweden are studied. Figure 1 shows a schematic of biogas production and use.

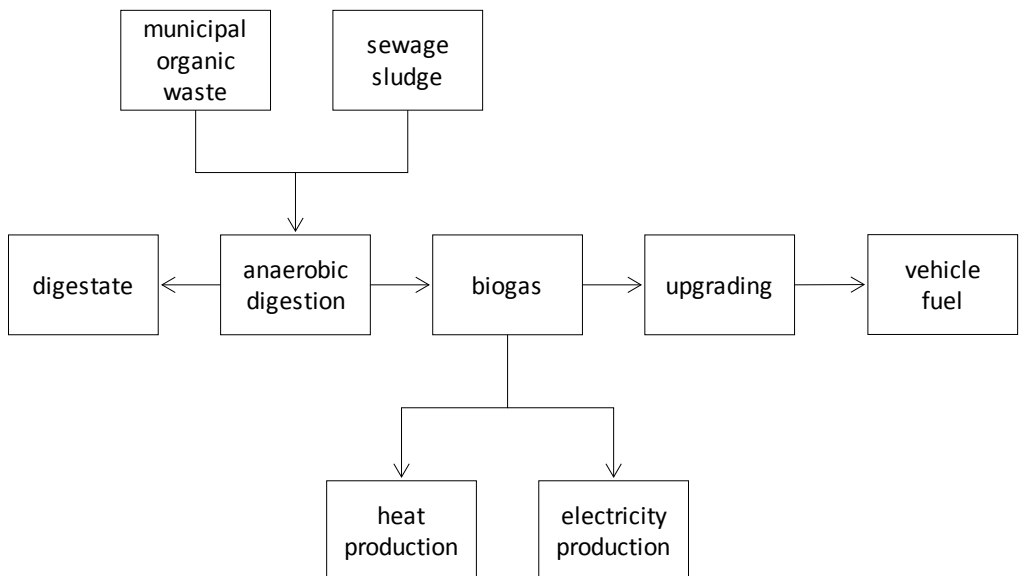

Figure I. Biogas production and use, as studied in papers II and III. 
Biogas can be produced from the anaerobic digestion or gasification of biomass. Here, only biogas produced by anaerobic digestion is considered. Common substrates used in this process include sewage sludge, municipal organic waste, manure and other farm waste, and waste from food industries. The digestion of these substrates produces a gas that contains methane, carbon dioxide and impurities such as hydrogen sulphide (Ryckebosch et al., 2011). This raw biogas may be used in electricity or heat production. If raw biogas is cleaned of carbon dioxide and impurities in an upgrading process, it reaches natural-gas quality, which means that its methane content is high, over $97 \%$. At this point it may be injected into a natural gas grid and used just like natural gas (Åhman, 2010). Using upgraded biogas as a vehicle fuel has become common, especially in urban public transport (Fallde, 2011). Yet biogas holds a very small share of total energy use. In 2012, only 0.8 TWh of biogas was used in road transport, less than $1 \%$ of the energy used in all national Swedish transport (SEA, 2014).

The by-product of biogas, digestate, can be used as fertiliser, which is an excellent way of bringing nutrients back into the ecological system. For example, plants take up nitrogen from digested manure more easily than from undigested manure; and phosphorus, which needs to be mined to produce artificial fertiliser, is recycled in digestate (Berglund, 2006).

Biogas has great potential to reduce GHG emissions when used to replace fossil fuels, especially if it is produced from waste products, as is usually the case (Magnusson, 2012b). Depending on the raw material and the production processes, biofuel use can result in both lower and higher GHG emissions compared to fossil fuels (Börjesson, 2009). For example, indirect effects from land use when growing energy crops for biofuels can cause high GHG emissions (Fargione et al., 2008; Searchinger et al., 2008). Utilising waste as a substrate, however, implies low GHG emissions, as no virgin resources are required. The use of digestate as a replacement for artificial fertiliser further improves calculations of GHG emissions from biogas, as fossil-fuel use can then be avoided in fertiliser production (Berglund, 2006).

There is currently plenty of research on biogas production. Swedish studies recognise a potential for biogas production of up to $17 \mathrm{TWh}$, which equals $20 \%$ of current energy use in the transport sector (Magnusson, 2012b; SEA, 2014). However, the potential for biogas production and GHG reductions might not be realised although studies show that it exists and suggest how it could be realised. For example, Lybæk et al. (2013) have shown how the dynamic and non-linear nature of the development process in this field means that basic biogas research does not automati- 


\section{Chapter 2}

cally lead to technological innovation. This indicates that studying the production and use of biogas from more perspectives than purely technical ones is desirable.

\subsection{Electric vehicles}

An automobile powered by electricity falls under the definition of an electric vehicle. This term comprises several automobile technologies. Hybrid electric vehicles may switch between an electric motor and a combustion engine. In conventional hybrids, electricity is generated while driving, for instance by converting brake energy to electricity. Plug-in hybrid electric vehicles also have both an electric motor and a combustion engine, but they can be recharged by connection to the electricity grid. Plug-in electric vehicles operate only by an electric motor and are recharged by connection to the electricity grid (Tie and Tan, 2013). In this thesis, the term 'electric vehicle' refers exclusively to a plug-in electric vehicle.

In papers IV and V, electric vehicles and their energy supply are studied from a European perspective. These papers discuss implications for GHG emissions, depending on energy source. An electric motor does not produce exhaust gases, so the vehicle itself has no GHG emissions. However, GHG emissions occur as a result of electricity production. Including the electricity used by the vehicle in a GHG-emission assessment thus gives an estimate of the GHG emissions caused by driving an electric vehicle. Therefore, papers IV and V essentially focus more on electricity production than on electric vehicles.

Electric vehicles are often considered to be emission-free, either because they lack tailpipes or because they are assumed to use renewably produced electricity. However, prognoses show that European electricity production will remain largely fossilfuel based. By 2050, it is estimated that $50 \%$ of European electricity will be produced renewably (EC, 2014; Klessman et al., 2011; Lise et al., 2013; Möst and Fichtner, 2010). Therefore, electric vehicles need to be studied using different perspectives, in order to identify how they can contribute to reducing GHG emissions from energy and transport systems.

The relationship between electric vehicles and electricity production is also rather intricate. Not only do the GHG emissions caused by electric vehicles depend on the means of electricity production, but the electricity production also depends on when the electric vehicles are charged. As electricity production always matches electricity demand, the production can be managed through demand-side measures. If electric vehicles are charged in the early evening, when electricity demand usually peaks, the demand peak will rise; thus, this timing might result in a need for new electricity 
production. If the charging occurs at a time when electricity demand is low, it can help to level out the electricity demand curve, and thus help stabilise electricity production (Grahn et al., 2012, 2013; van Vliet et al., 2011). Such phenomena should be studied from different perspectives, not merely a technical one, in order to understand the dynamics of the system.

\subsection{District heating with CHP production and industrial excess heat}

In paper VI, methodologies for GHG-emission assessments are studied with regard to district heating systems with CHP production and/or industrial excess heat. Figure 2 shows a schematic of such a system.

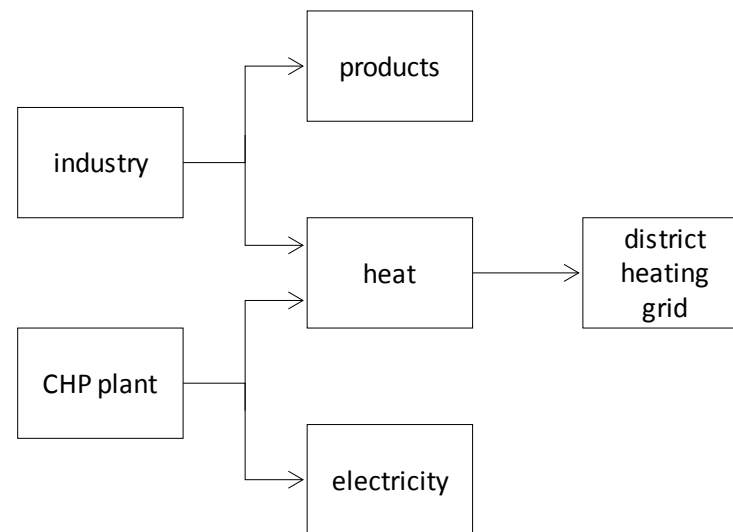

Figure 2. Production and use of heat, as studied in paper VI.

In a district heating system, hot water is distributed to households, companies and industries, with an emphasis on multi-family dwellings, with the purpose of providing space heating and hot tap water. The heat is produced in heat plants, CHP plants or provided by certain industries that have excess heat from their production processes. Basically, any kind of fuel may be used. In a CHP plant, heat is cogenerated with electricity. Although a CHP plant has a lower electrical efficiency than a condensing power plant and a lower heat efficiency than a heat plant, the total efficiency of a CHP plant is greater than that of separate heat and electricity production (Odenberger et al., 2009).

District heating has been widely studied with regard to reducing GHG emissions from energy systems (e.g., Connolly et al., 2014; Lund et al., 2014; Rezaie and Rosen, 2012). Environmental benefits such as GHG-emission reductions are mainly caused by more efficient resource use; for example, excess heat can be utilised, and CHP production can substitute for the separate production of heat and electricity. 


\section{Chapter 2}

In addition, district heating systems with CHP plants have been shown to reduce GHG emissions when the electricity produced by the CHP plants is assumed to replace electricity produced separately (Difs, 2010; Henning and Trygg, 2008). The use of district heating has also been shown to imply GHG-emission reductions when it replaces the use of electricity (Djuric Ilic and Trygg, 2014; Henning and Trygg, 2008). However, showing opportunities for GHG-emission reductions does not mean that these technologies will be implemented. Magnusson (2012a) demonstrated that the Swedish district heating sector is stagnating. It has also been shown that resource and energy-efficient measures, such as choosing district heating instead of electricity, are sometimes not implemented in industry or in the building sector, even though knowledge is not lacking (Palm, 2013; Palm and Thollander, 2010). Reducing GHG emissions by the use of district heating should thus be studied from a wider perspective, rather than from a purely technical viewpoint.

In a European context, industrial excess heat is prevalent, but is not commonly used in district heating systems (Persson and Werner, 2012). There is great potential for increased use of industrial excess heat (Connolly et al., 2014). For example, in a case study of a Swedish county, Broberg Viklund and Johansson (2014) found that 0.8 TWh, or $8 \%$ of the studied companies' energy use, could be recovered annually and used in a district heating system. However, using excess heat in district heating systems can be problematic both in terms of environmental performance and security of supply. A district heating system can be burdened by fossil-fuel use if the industry uses fossil fuels in their production processes, and by its dependence on another actor. These are two reasons why more than purely technical analyses are needed when studying how industrial excess heat can contribute to reducing GHG emissions from energy systems. 


\section{A systems approach}

A system is generally defined as a collection of components that are separated from the environment by a system boundary, and the interrelations between these components (Ingelstam, 2012). The system concept can be applied at any level of complexity and in all disciplines. For example, a gas turbine can be considered a system within a power-plant environment, and a community can be considered a system in which a power plant is a component. The latter is an example of a sociotechnical system, in which society is intertwined with technology (Geels, 2004; Summerton, 1994). In a sociotechnical system, technical artefacts cannot be separated from the society in which they exist, because technology is affected by society and society is affected by technology.

This thesis is based on sociotechnical system studies, but also on a background of energy system analysis. Energy systems can be defined as sociotechnical, as they typically include both technical components, such as energy conversion and distribution technologies, and societal components, such as energy users, energy utility managers and policy (e.g., taxes and regulations). Depending on the aim of a study, different system boundaries are appropriate. In the appended papers, different systems are studied with different objectives, and thus different system boundaries are used.

\section{I Energy systems analysis}

In the mid- $20^{\text {th }}$ century, systems theory emerged as a concept in which mathematics was used to model interdisciplinary issues. One of its main applications was within operations research, in which military missions were planned. In civilian domains, systems theory was used to solve optimisation problems such as route-planning and store-keeping. Some researchers intended for systems theory to encompass even more, such as becoming a scientific skeleton on which to hang disciplinary science 


\section{Chapter 3}

(Boulding, 1956), or a framework to solve humankind's great social problems (Churchman, 1968). According to these researchers, using a systems approach implied that different disciplines would come together in solving problems, and that the nature of the problem at hand would determine which methods should be used - as opposed to disciplinary research, which focuses on specific problems and methods.

Energy systems analysis, as understood in this thesis, is largely based on mathematical models of energy systems. It has been extensively used to identify potential for economic gains and GHG-emission reductions. For example, Grahn et al. (2012, 2013) show how Markov models can be used to identify how electric vehicles can reduce user costs and GHG emissions. In a Swedish context, optimising models have been used to find the optimal location for biofuel production plants (Leduc et al., 2010a, 2010b); to identify the economic and environmental benefits of introducing biomass gasification in a district heating system (Difs et al., 2010); and to link biofuel production, district heating and forest industry in industrial symbiosis (Karlsson and Wolf, 2008). In an international outlook, energy system models have shown that the projected increase in transport demand necessitates technological changes in the transport system in order to reduce GHG emissions (Girod et al., 2013). Several modelling studies have identified complex dependencies between energy and transport systems (e.g., Anable et al., 2012; Bale et al., 2015; Grahn et al., 2009; Keirstead et al., 2012), thereby establishing the need for research that connects these two systems.

The above-mentioned studies contain numeric parameters. Actors, actions and decision making are represented by costs. This simplified representation of reality can be a very useful tool, but it is constrained with respect to behaviour and social structure. There have been many attempts to include behaviour in models, but more research is needed in order for this inclusion to be useful (Tran, 2014). There is also a risk that when reality does not converge with a model, people will be considered problematic rather than the model (Moezzi and Janda, 2014).

\subsection{Sociotechnical systems analysis}

While energy systems analyses are typically based on positivism, sociotechnical system studies are more or less based on social constructivism (Bijker, 2013; Collins, 2013; Radder, 2013). In a positivistic approach, optimal solutions that are identified when studying a technical artefact are viewed as optimal regardless of the artefact's societal environment. Within social constructivism, it is assumed that society constructs the 
artefact, and vice versa; thus, there is no point in studying an artefact outside of its societal environment.

Studies of sociotechnical systems are more or less focussed on the relationship between society and technology. The theory of large technical systems, which explains the different phases of system development as functions of the interaction between technology and actors (Hughes, 1983; Summerton, 1994), emphasises that technology and society are intertwined. Other theories, such as actor-network theory, find actors to be of greater importance and emphasise how society constructs technology (Latour, 1987). Yet another example of a sociotechnical theory is transition theory, which explains technological development by describing a technology's transition through different societal regimes (Geels, 2004).

The usefulness of sociotechnical systems analysis has been demonstrated in several energy system studies. For example, Magnusson (2012a) analysed Stockholm's district heating system using large technical systems theory. He found that the system in question was stagnating, due to changes in society. This finding is of interest, because energy systems analyses have identified great potential for district heating. Transition theory has been used not only to explain the development of a technology, but also to explain why some technologies are not developing as expected. For example, Nykvist and Nilsson (2014) explained the slow uptake of electric vehicles in Stockholm despite policy support, and Jacobsson and Karltorp (2013) identified organisational barriers against offshore wind power, despite wind power being a well-known and uncontroversial technology. Bolton and Foxon (2015) showed how an understanding of technology development processes, gained by sociotechnical system studies, could be operationalised to encourage investment in renewable energy.

By applying a sociotechnical approach, the above-mentioned studies were able to incorporate non-numerical parameters, such as norms and relationships between decision-makers. Thus, they were well equipped to study processes. While a mathematical energy systems analysis can suggest technological opportunities, a sociotechnical systems analysis can explain the role of technology in society. This is not to say that sociotechnical system studies only find barriers towards development, or that energy systems analyses only identify potential for development. The main implication is a need to use a variety of different approaches and methods when studying complex problems. For example, a sociotechnical approach can provide an understanding of how energy issues are handled in policy, industry and research, thus facilitating the understanding of the wicked problem of reducing GHG emissions from energy and transport systems. 


\section{Methodology and material}

In this thesis, different methods are used to study different sociotechnical systems. Here, these methods are described with focus on their use in the particular context of this thesis. Therefore, this chapter presents the analytical framework that is applied in the appended papers. This encompasses which methodological choices that are made and how the material is interpreted and analysed, and is a relevant foundation for analysing and discussing the research questions.

An overview of which methods that are used in which papers is provided in Table 4. In this chapter, each method is presented with the analytical frameworks that are applied in the papers. As research design and data collection are presented in detail in the appended papers, it is not repeated here.

Table 4. Overview of methods used in the appended papers.

\begin{tabular}{lcccc} 
& $\begin{array}{c}\text { GHG emission } \\
\text { assessment }\end{array}$ & $\begin{array}{c}\text { Document } \\
\text { studies }\end{array}$ & Interviews & Backcasting \\
\hline Paper I & & $\mathbf{x}$ & $\mathbf{x}$ & $\mathbf{x}$ \\
\hline Paper II & $\mathbf{x}$ & & $\mathbf{x}$ & \\
\hline Paper III & & $\mathbf{x}$ & & \\
\hline Paper IV & $\mathrm{x}$ & & & \\
\hline Paper V & & $\mathbf{x}$ & & \\
\hline Paper VI & $\mathrm{x}$ & & & \\
\hline
\end{tabular}

\section{I Greenhouse gas emission assessments}

Three of the appended papers, namely II, IV and VI, use GHG-emission assessments. A GHG-emission assessment, when performed in an energy systems analysis, shows the resulting GHG emissions from energy conversion or use. Such an assessment can be performed within any system boundary. A GHG assessment can, for 


\section{Chapter 4}

example, include only the direct GHG emissions from the tailpipe of a vehicle; include all indirect GHG emissions that may be related to the vehicle, such as GHG emissions from fuel production; or, extending even more, include emissions from a whole vehicle fleet. Transparency with regard to the system boundary is a requirement in order for the results of GHG-emission assessments to be comparable.

A GHG-emission assessment can be attributional or consequential. An attributional assessment calculates GHG emissions of energy conversion or use that have already occurred. In a consequential GHG-emission assessment, the consequences of changes to a system, such as changes in energy conversion or energy use, are assessed (Ekvall et al., 2005; Finnveden, 2008). How far the consequences of change reach depends on the system boundary. This thesis primarily uses a consequential approach.

\section{I.I System boundaries used in the papers}

Paper II analyses the consequences of the increased demand for biogas as a vehicle fuel, and its impact on municipal organic-waste management. GHG emissions are assessed with regard to different ways of handling municipal organic waste. Life-cycle GHG emissions are considered when using municipal waste as fuel in CHP production or in biogas production. The produced biogas is assumed to either be used as fuel in CHP production or to be upgraded and used as vehicle fuel. Any electricity produced using biogas or municipal organic waste is assumed to replace other electricity, and any biogas used as vehicle fuel is assumed to replace petrol or diesel. The system is illustrated in Figure 3. 


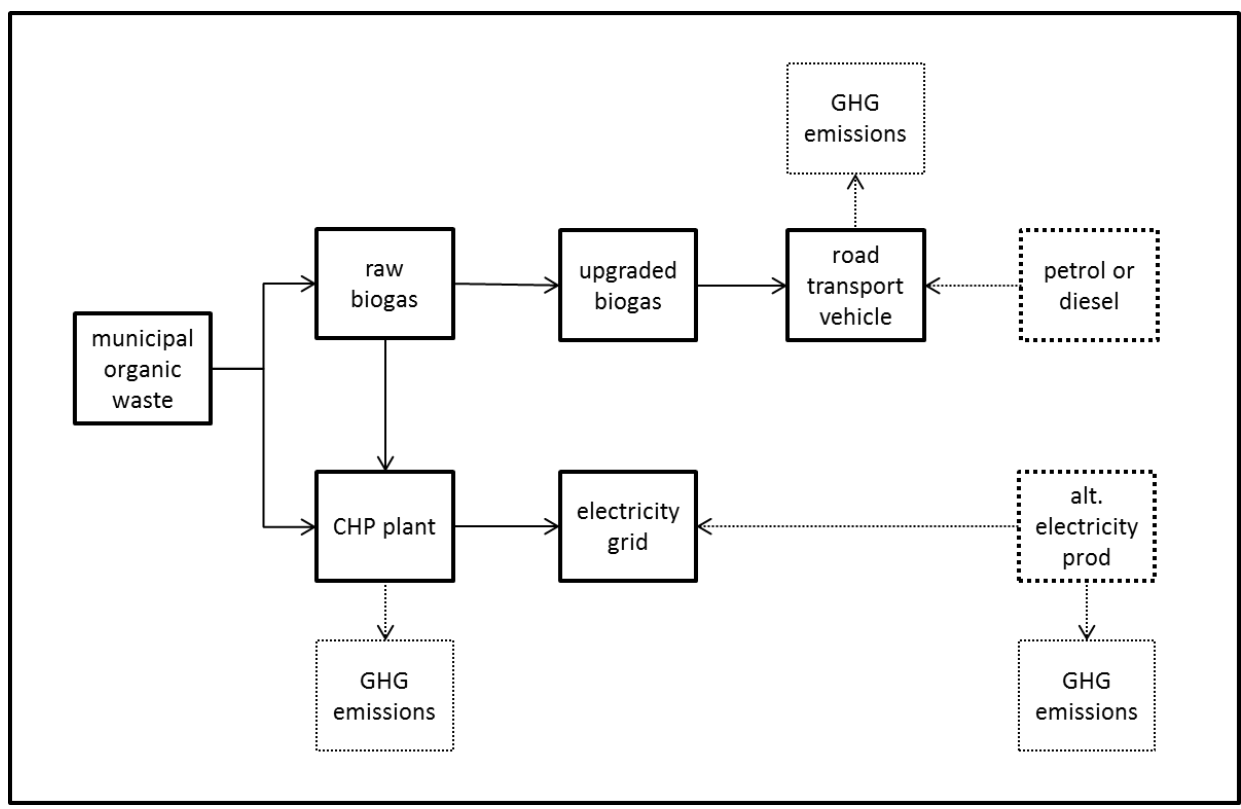

Figure 3. The system that is studied in paper II.

Paper IV analyses the increased electricity demand that is the consequence of an introduction of electric vehicles. GHG emissions from electric vehicles are assessed in a life-cycle perspective and compared to other options for individual road transport. The system includes the electric vehicle and the electricity production, and the system boundary is varied with respect to electricity production. The electric vehicle is assumed to use different options for Swedish or European electricity production depending on the system boundary. The system is illustrated in Figure 4.

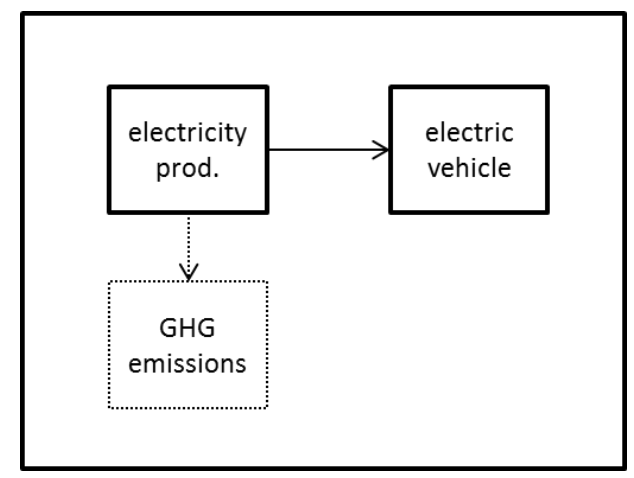

Figure 4. The system that is studied in paper IV. 


\section{Chapter 4}

Paper VI analyses the consequences of changes due to the addition of a CHP plant and industrial excess heat to a district heating system. Assessments of GHG emissions in district heating systems with CHP production and industrial excess heat are examined. The system includes the district-heating grid, a CHP plant, an industry with excess heat and the alternatives that the heat and electricity produced within the district heating system are assumed to replace. Several different options for alternative electricity and heat production are considered. The system is illustrated in Figure 5.

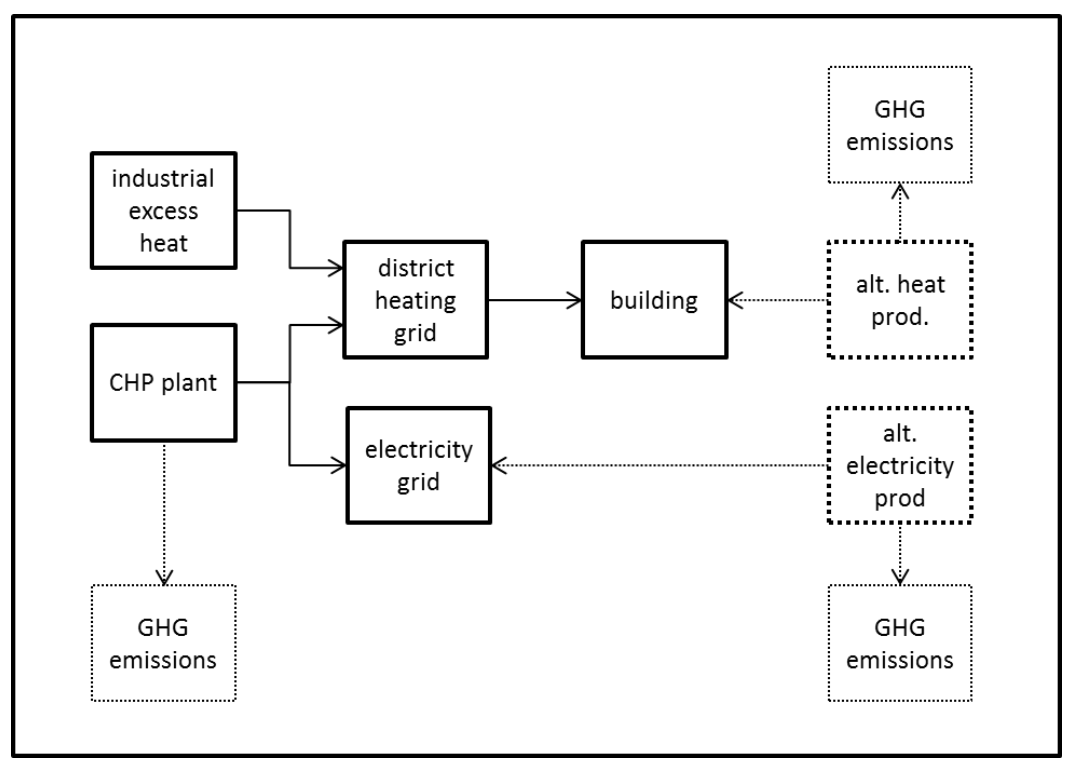

Figure 5. The system that is studied in paper VI.

\section{I.2 A consequential approach to electricity production and use}

With regard to electricity, this thesis uses different options for marginal and average electricity production. These concepts refer to different ways of viewing electricity consumption. When accounting for electricity use in an attributional assessment, a national or regional average production mix is often used. This is acceptable for bookkeeping calculations, when the electricity supply and demand are known (Dotzauer, 2010; Sjödin and Grönkvist, 2004). With regard to consequential assessments, where changes in supply and demand are considered, it is not appropriate to use average figures. Instead, researchers advocate the use of marginal electricityproduction figures (Dotzauer, 2010; Sjödin and Grönkvist, 2004; WRI, 2007). 
Changes to supply and demand are assumed to affect the electricity production margin, that is, the last produced unit of electricity in the system. Depending on the time frame, the marginal production is based on different assumptions. Changes to the current system are assumed to affect the operating margin, while changes to a future system are assumed to affect the build margin. The latter is constructed based on assumptions about future electricity production. Currently, coal condensing power is usually assumed to be on the operating margin. Looking ahead, to 2020-2030, natural gas or modernised coal condensing power plants are often assumed to be on the build margin (Axelsson et al., 2009; Djuric Ilic et al., 2014).

\section{I.3 Industrial symbiosis as an analytical framework}

Paper VI discusses the impact on GHG emissions of resource use in district heating systems. For this purpose, the concept of industrial symbiosis is used. This concept involves increasing resource efficiency through co-operation between industries (Chertow, 2000). In industrial symbiosis, industries exchange resources such as water, energy and materials. It is a means of 'closing the loop', as one industry's byproduct or waste can be used as another industry's raw material. The concept of industrial symbiosis is considered appropriate with regard to district heating systems, as these systems provide arenas where several resource collaborations are possible. CHP plants can engage other industries in industrial symbiosis, thus functioning as so-called 'anchor tenants' (Martin and Eklund, 2011). A CHP plant can either utilise other industries' waste as fuel, provide other industries with heat, electricity and/or steam, or engage in both kinds of symbioses. Industries can collaborate with energy utilities by providing excess heat to a district heating system (Broberg Viklund and Johansson, 2014).

Environmental assessments of industrial symbiosis often compare the benefits of cooperation around resource use to a reference case without such co-operation, focussing on local opportunities (Martin et al., 2014; Sokka et al., 2011). Thus, environmental benefits (such as GHG-emission reductions) from a particular industrial symbiosis can be quantified. In paper VI, such quantifications are not made. Instead, this paper discusses the sociotechnical dimension of industrial symbiosis, along with possible implications for local opportunities. The feasibility of cooperation between industries and energy utilities is discussed, not only with regard to technical possibilities but also to social and economic factors. Thus, assessments of GHG emissions can be performed on a foundation of local conditions and requirements with regard to heat. 


\section{Chapter 4}

\subsection{Document and interview studies}

Four of the appended papers, namely papers I, II, III and V, are largely based on analyses of documents and interviews. This section presents the selection of material and describes the use of different theories in analysing the material.

\subsection{Policy integration as an analytical framework}

Paper I studies a policy process. Policy documents guiding or governing the policy process were studied, and civil servants that were active in the policy process were interviewed. Policy documents were selected based on the criteria that they treated transport planning in the Stockholm region and were issued between 2007 and 2011. Interview respondents who worked with issuing such policy documents or implementing transport policy were selected, as they could provide information about the values and reasoning behind the documents and how the documented policy was used and implemented. The documents and the interview material are analysed qualitatively, with a view to understanding the policy process.

Transport and energy policy processes can be described as parallel (Fallde, 2011). The same issues are discussed simultaneously but separately in the transport policy sector and the energy policy sector, which can lead to contradictory policy decisions being made in the parallel policy sectors. Policy integration is important in order to prevent policy decisions from being contradictory (Geerlings and Stead, 2003; Söderberg, 2011). Paper I studies policy integration between the transport and energy policy sectors using three concepts: problem definition, policy measure and policy goal (cf. Rouillard et al., 2013). A problem definition is the representation of an issue that should be addressed by policy-makers. In the policy process, the problem definition is turned into a concrete policy goal, which policy aims to achieve through the implementation of policy measures. By identifying the problem definitions, policy measures and policy goals within energy and transport policy, similarities and discrepancies can be found. These show how issues are handled within the transport and energy policy sectors. An analysis of how the policy processes in different policy sectors manage different issues can display occurrences of parallelism and integration between the sectors. Thus, the policy integration of transport and energy policy can be described.

\subsubsection{Acquiring information through qualitative interviews}

The interview material used in paper I is also used in paper II, where it is complemented by additional interviews. In paper II, interviews are used to explain the polit- 
ical interest in biogas and the development of biogas production in the Stockholm region. Therefore, the interviews with civil servants working with transport policy are complemented by interviews with a politician and a businessman, who were both involved in biogas production. The interview material is analysed qualitatively in order to understand opinions, attitudes and actions.

\subsubsection{Large technical systems theory as an analytical framework}

Paper III studies the development of biogas production and use in Sweden. For this purpose, documents that contain quantifiable information (e.g., statistics, regulations) about biogas production and use are analysed. In general, scientific publications and reports from public authorities and trade organisations were selected for this study. The content of these documents is analysed in a quantitative manner, with a focus on facts such as the year a specific biogas plant was built and which substrate it utilised. Concepts from the theory of large technical systems are used when analysing the documents, to explain the development of biogas as a sociotechnical system. This theory describes system development by identifying phases (e.g., invention, expansion, stagnation) and concepts (e.g., system builders, momentum) within a sociotechnical process (Hughes, 1983; Magnusson, 2012a; Summerton, 1994). It has mainly been used to explain development of systems that have a large infrastructure, such as electricity grids and railways.

The suitability of using large technical systems theory to analyse a biogas system may be questioned, as this system does not (yet) have one specific infrastructure that governs the whole system. Therefore, the analysis is limited to the use of two concepts that explain how technology adapts to the society in which it is used. These concepts are technology transfer and technological style. Technology transfer denotes the spreading of technology from one context to another, for example between different regions or sectors. Different contexts have different social and technological prerequisites, which means that the same technology may develop different features in different contexts. Thus, technology transfer helps shape technology in different ways, giving it different technological styles (Hughes, 1983; van der Vleuten, 2009). Using the concepts of technology transfer and technological style can help to define and categorise aspects of system development, thus explaining characteristics of that specific system.

\subsubsection{Framing theory as an analytical framework}

Paper $\mathrm{V}$ studies the framing of electric vehicles in EU policy through analyses of EU policy documents guiding or governing sustainable transport. Comprehensive doc- 


\section{Chapter 4}

uments, such as directives and strategies, issued between 2009 and 2013, were selected for this study. The selected documents are assumed to provide insight into how European transport and energy systems are approached by policy, both now and in the near future. The documents are analysed qualitatively, using questions about which problems that are solved by electric vehicles and how these vehicles are intended to solve them, inspired by Bacchi's (2008) approach to framing theory.

The representation of policy issues is central in framing theory, which explains policy and public debate as a result of the framing of issues (Bacchi, 2008; Chong and Druckman, 2007; Peoples, 2014). A problem can be defined, or framed, in different ways, and depending on how it is defined it will influence policy and public debate differently. The framing of a policy issue can influence how it is handled in the policy process and thus affect the creation of policy goals and the implementation of policy measures. Knowing how electric vehicles are framed is helpful when investigating the future consequences of electric-vehicle policy.

\subsection{Backcasting}

Paper I is partly based on a study of a future road transport system. Therefore, scenario methodology was used. Scenario studies can be divided into three segments: forecasting, exploratory and backcasting approaches (Banister and Hickman, 2013). In the forecasting approach, predictions about the future are made based on current trends. In the exploratory approach, scenarios are created and used together with the question "What if?" Thus, different options and their consequences can be explored. In the backcasting approach, desired future scenarios are constructed and the means by which the scenarios may be reached are analysed.

Paper I uses the backcasting methodology. Two scenarios are constructed, in which road transport in the City of Stockholm will exclusively use renewable energy by 2030. One scenario is dominated by biofuels, and the other is dominated by electric vehicles. The main aim of backcasting is usually to identify the actions that are required in order to reach a future scenario. Backcasting is considered particularly useful when radical change is required in order to reach environmental goals (Höjer and Mattsson, 2000). Polarised future scenarios are commonly developed and used to show the difference in policy implications, depending on which future - and which pathway to achieve it - is selected (Dreborg, 1996). Desired future scenarios are usually based on technological and economic considerations (Robinson, 1990).

Although policy implications are often the result of backcasting studies, the plausibility of realising the scenarios is rarely discussed. While backcasting studies show a 
need for radical change, research on societal development shows that change happens slowly and incrementally (Hatzopoulou and Miller, 2008; Marsden et al., 2014). Thus, if implementable scenario studies are desired, there could be a need to modify the methodology. Previous research has identified a need to increase the pragmatism in backcasting, in order to achieve more implementable results (Banister and Hickman, 2013). In paper I, this was attempted by combining backcasting with policy analysis. 


\section{Results and discussion}

In this chapter, the research questions are analysed and discussed based on findings from the appended papers. Table 5 presents an overview of which research questions that are addressed by each paper.

Table 5. The relationships between papers and research questions (RQs).

\begin{tabular}{lcccccc} 
& Paper I & Paper II & Paper III & Paper IV & Paper V & Paper VI \\
\hline RQ I & & $\mathbf{x}$ & & $\mathbf{x}$ & & $\mathbf{x}$ \\
\hline RQ II & $\mathbf{x}$ & $\mathbf{x}$ & $\mathbf{x}$ & & $\mathbf{x}$ & \\
\hline RQ III & $\mathbf{x}$ & $\mathbf{x}$ & $\mathbf{x}$ & $\mathbf{x}$ & $\mathbf{x}$ & $\mathbf{x}$ \\
\hline
\end{tabular}

\section{I Research question I: How does the choice of system boundaries affect the results of energy system research?}

GHG emissions from energy and transport systems are often evaluated in energy systems analyses. The figures derived from such analyses can be used in subsequent evaluations or as a basis for decision-making. Research has shown that the results of GHG-emission assessments differ, depending on which methods are used and which assumptions about input data are made (e.g., Borrion et al., 2012; Börjesson, 2009; Sjödin and Grönkvist, 2004; Wetterlund et al., 2010). Thus, these results can be difficult to use as they are products of their context. Used appropriately, the results of GHG-emission assessments can be part of workable solutions to reduce GHG emissions; however, if used out of context, they can instead add to the "wickedness" of reducing GHG emissions from energy systems.

The use of GHG-emission assessment results is a complex issue due to the risk that these figures may be misleading if used out of context. The complexity of this issue is illustrated by examples from the appended papers. Based on the data from these 


\section{Chapter 5}

examples, it could be concluded that producing vehicle fuel from municipal waste or recycling industrial excess heat could increase GHG emissions, while building a fossil-fuelled CHP plant could reduce GHG emissions. These statements may seem strange, but as this section will show, in their particular contexts these conclusions are valid. In this section, the choice of system boundaries and methodological approaches in GHG-emission assessments of energy systems is problematised. This discussion is based on the input data, system boundaries and methodology used in papers II, IV and VI, and on the results from these papers. This section also identifies and discusses implications for the reduction of GHG emissions from energy and transport systems.

\section{I.I Results from papers II, IV and VI}

Paper II calculates GHG emissions from different usages of municipal organic waste. The results show that depending on system boundaries, using the waste as biogas substrate and then using the biogas to fuel heavy-duty vehicles either increases or reduces GHG emissions from the system. The outcome depends on whether the biogas is considered to have an alternative utilisation or not. If it is assumed that the only use for biogas is to replace fossil-based vehicle fuel, then GHG emissions are shown to be reduced. However, other utilisations exist that may reduce GHG emissions even more. If these more effective utilisations are included within the system boundary, using the biogas for vehicle fuel rather than for these applications can result in an overall increase in GHG emissions. In paper II, it is assumed that municipal organic waste can be used in CHP production, and that the electricity from such a CHP plant can replace marginal electricity production (which in this case is assumed to be coal-fuelled). These factors result in a reduction of GHG emissions that exceeds the reduction from using biogas as a vehicle fuel (which is assumed to replace diesel use). Figure 6, which is adapted from paper II, illustrates this comparison. 


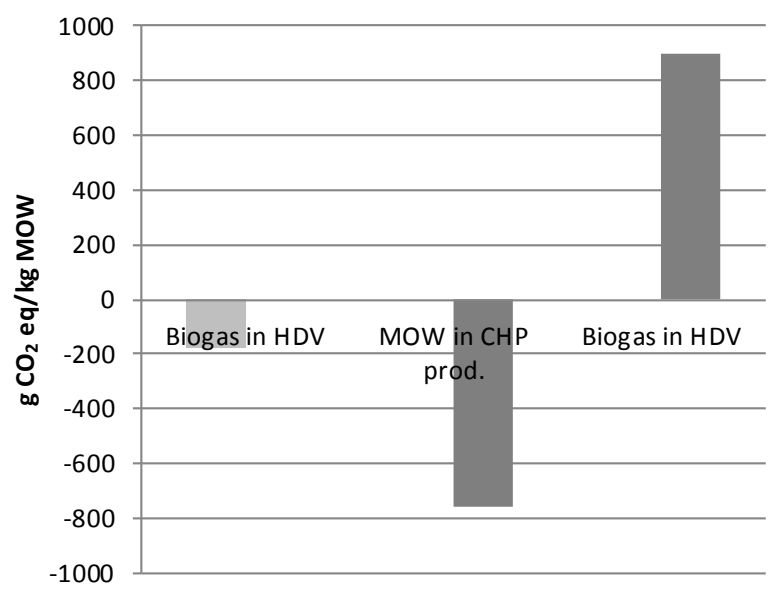

No alternative use for MOW

Alternative use: CHP prod.

Figure 6. GHG emissions from the use of biogas or municipal organic waste (MOW), given different system boundaries. The lighter bar on the far left represents GHG emissions from using biogas as a fuel for heavy-duty vehicles (HDVs), thus replacing diesel use. In this case, no alternative utilisation of MOW is assumed. The two darker bars on the right represent GHG emissions from using MOW in CHP production or biogas in HDVs, assuming both to be options. In this case, either biogas replaces diesel as vehicle fuel, or CHP-produced electricity replaces electricity from coal-condensing power plants. One alternative use is assumed to exclude the other.

Paper IV calculates GHG emissions and energy use from plug-in electric vehicles, and illustrates how the results depend on assumptions about electricity production. Several different electricity-production technologies are used as input. The results show that if electric vehicles are assumed to use an average mix of Swedish electricity production, they cause low GHG emissions. On the other hand, if electric vehicles are assumed to use coal-condensing marginal electricity production, they cause roughly the same quantity of GHG emissions as conventional, fossil-fuelled vehicles. Figure 7, which is adapted from paper IV, illustrates this comparison. In this case, the system boundary varies with regard to assumptions about the electricity system. 


\section{Chapter 5}

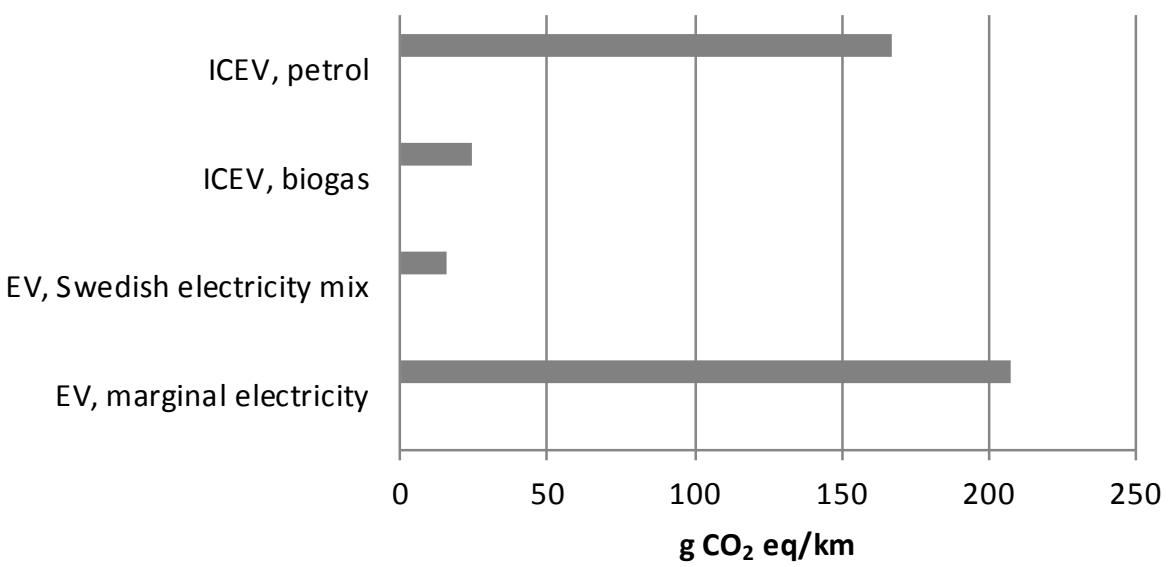

Figure 7. GHG emissions from passenger cars: internal combustion engine vehicles (ICEVs) using petrol or biogas, and electric vehicles (EVs) using electricity from different production processes.

Paper VI illustrates the outcomes of using different system boundaries and methodologies when assessing GHG emissions from district heating systems with naturalgas-fuelled CHP production and industrial excess heat. The district heating systems discussed in this paper include alternative options for the production of heat and electricity; thus, opportunities for GHG-emission reductions depend on assumptions about various production processes.

Assuming that industrial excess heat carries zero GHG emissions, the use of excess heat to replace other heat implies GHG-emission reductions. It is also assumed that CHP-produced electricity replaces marginal electricity production. GHG emissions from district heating systems are thus shown to depend on marginal electricity production, just as emissions from electric vehicles are shown to do in paper IV. Assuming that fossil-fuel-condensing power plants are replaced with CHP plants, GHG-emission reductions can be achieved. In addition, if CHP production and industrial excess heat are viewed as competitors, it can be shown that CHP plants cause greater GHG-emission reductions, since the replacement of fossil-fuel electricity production overshadows the replacement of heat production. Figure 8, which is adapted from paper VI, illustrates this comparison. 


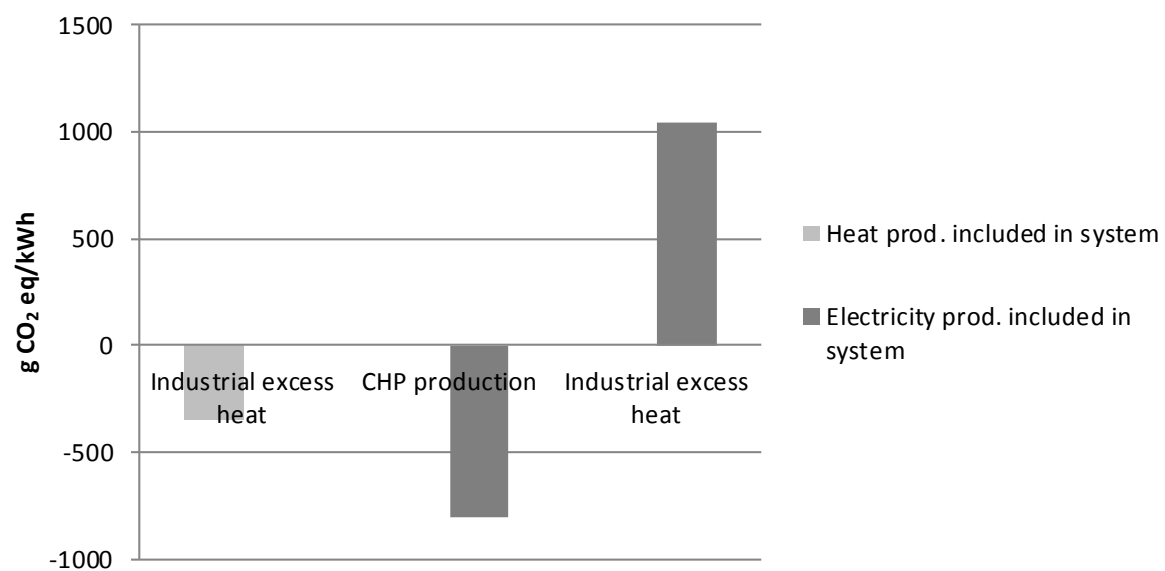

Figure 8. GHG emissions from district heating, given different system boundaries. The lighter bar on the far left represents GHG emissions from industrial excess heat, which is assumed to replace individual oil boilers (the system boundary is drawn around heating). The two darker bars on the right represent GHG emissions from a district heating system with either CHP production or industrial excess heat, where the system boundary is drawn around the electricity system. In this case, CHP-produced electricity is assumed to replace coal-based marginal electricity. Using industrial excess heat in this system implies a "loss" of CHP production, which can be shown as an increase in GHG emissions.

\section{I.2 Implications for GHG emissions}

In papers II and VI, the system boundary is varied with respect to alternative technologies in order to show the implications of different technology use on the results. These papers show that estimated GHG emissions depend on whether or not alternative technologies are included in a system. For example, when CHP production is included as an alternative technology in a studied system, the use of biogas and industrial excess heat instead of CHP may in fact be shown to increase GHG emissions from the system. This effect is largely due to assumptions about electricity production that are made in these two papers. The same assumptions are made in paper IV. In this paper, a consequential approach is used, and marginal electricity production is assumed to be affected by changes in the studied system. Generally, the marginal electricity production is assumed to occur in coal-condensing power plants, although papers IV and VI also include other alternatives.

The assumption made in paper IV, that a large-scale introduction of electric vehicles will result in new European fossil-fuel-powered plants, is not unreasonable. However, the effect of electric vehicles also depends on when they are charged - that is, if they add to peak load, or if they help to even out the load over the day. Different 


\section{Chapter 5}

electricity-production processes could be considered marginal production depending on the charging pattern. If smart grids enabled electric vehicles to be used as power sources as well as being charged with power from the grid, then electric vehicles could help regulate the system, thus enabling a larger share of solar and wind power. This regulation would also affect the marginal electricity production. Taking these features into account, the assumption that new electric vehicles would use additional coal-condensing power seems a little too simplistic.

The assumption in papers II and VI, that Swedish CHP production would replace European condensing power plants, is also a little simplistic. When required, electricity is traded between neighbouring countries (SEA, 2014). Sweden usually imports electricity during the winter, when heating demand rises, and exports surplus electricity during the summer, when hydropower conditions are good (SEMI, 2014). Additional CHP production could thus replace imported electricity in the winter, and add to exported electricity during the summer. As a result, Danish, German or Polish coal-condensing power plants could be replaced. However, new Swedish CHP production could also, for example, replace decommissioned nuclear-power production or meet a raised electricity demand. Although the replacement of marginal electricity production is one effect of a change in the system, it might not be the only effect.

Simplification of GHG-emission assessments can add complexity to the wicked problem of reducing GHG emissions from energy systems. A wicked problem cannot be solved by attempts at a simple solution; these attempts may add to the complexity of the issue and even create new problems (Fast and McCormick, 2012; Rittel and Webber, 1973). In other words, a solution that appears to be a simple way to reduce GHG emissions could lead to a new problem that needs to be solved. As paper IV shows, the use of electric vehicles could result in high GHG emissions. However, electric vehicles are frequently referred to as emission-free, and as such they are considered to be an easy solution for the problem of high GHG emissions from transport. This assumption could lead to more extensive use of electric vehicles, which could increase GHG emissions. Hence, the sustainability of the transport system could actually be reduced by the use of electric vehicles. Another simple solution involves taking for granted that new CHP production always replaces marginal, fossil-fuelled electricity production. This assumption places a higher environmental value on CHP production than if it were valued on its own - which would not be a problem if the assumption were always objectively true.

New CHP production may appear to be a simple solution, given GHG-emission figures such as those in Figure 8. However, in comparison with utilising available in- 
dustrial excess heat it adds to resource use and energy conversion, and as a result it can add complexity to the wicked problem. In the GHG-emission assessments in papers II and VI, resource use is central. In paper II, there is a choice between using municipal organic waste in vehicle fuel production or in CHP production. In paper VI, there is a choice between using industrial excess heat or CHP-produced heat. Such choices are affected by actual, tangible factors, such as the size of the community in question and whether or not it has a district heating grid. The amount of available municipal waste could determine its possible uses, and the demand for heating could determine appropriate possibilities for heat supply. One of the reasons why tangible factors must affect such decisions is simply that biogas production or district heating may not be economically viable in a small system. The need to address resource use is recognised in paper VI, in which reflections on resource efficiency are based on an industrial symbiosis framework.

Paper VI suggests that basing GHG-emissions assessments on evaluations of resource efficiency could make these assessments more useful, because they would be more nuanced. Taking local prerequisites, conditions and requirements into account could reduce the use of generalisations that may not be applicable. For example, in the cases discussed here, the actual potential for excess heat collaborations or biogas production could be considered, and the question of what the marginal electricity production actually is in the specific case could be raised. Although the system boundary could still encompass alternatives for energy conversion and use, the alternatives would be more specific.

As this section shows, the choice of system boundaries matters. Depending on where the system boundary is drawn, anything can be shown and its validity motivated. This section also shows that inappropriate selection of system boundaries can have a negative effect on sustainable development, adding to the complexity of the wicked problem even when results state that massive GHG-emission reductions can be achieved. In GHG-emission assessments such as those in papers II, IV and VI, the choice of system boundaries should depend on the system under study. Specifically selecting system boundaries for a studied system could make the results of the study more useful and more likely to be a valid part of an approach to reduce GHG emissions from energy and transport systems. 


\section{Chapter 5}

\subsection{Research question II: How do the system boundaries used in energy and transport policy affect the sustainable development of energy and transport systems?}

The sustainable development of energy and transport systems requires policy support (e.g., Jacobsson and Karltorp, 2013; Lybaek et al., 2013; Magnusson, 2012a; Nykvist and Nilsson, 2014), and at least gets policy attention. National and European policy often includes measures to achieve climate goals, such as reaching the $2^{\circ} \mathrm{C}$ target. Thus, policy is obviously concerned with the reduction of GHG emissions from energy and transport systems. However, a premise of this thesis is that measures to achieve climate goals are not implemented to a high enough degree. Thus, it is assumed that the presence of sustainable development issues in policy does not automatically mean that policy leads to GHG-emission reductions and thus to sustainable development. This section discusses the relationship between energy and transport policy and the sustainable development of energy and transport systems. The focus is on how system boundaries pervade policy and policy-making, and how the use of system boundaries can affect the development of energy and transport systems.

\subsection{System boundaries in energy and transport policy: Findings from pa- pers I, II and V}

Paper I studies the integration between energy policy and transport policy in the Stockholm region. By identifying problem definitions, policy measures and policy goals within the two policy sectors, evidence of parallel policy processes was found. Energy and transport policy were found to share problem definitions, but to concretise them into separate policy goals, and to suggest separate policy measures to reach their respective goals. Both policy sectors found increasing GHG emissions to be problematic. Energy policy approached this issue through policy measures regarding renewable fuels and energy-efficient vehicles, particularly biogas fuels and electric vehicles. On the other hand, transport policy focussed on maintaining mobility through policy measures regarding infrastructure and public transport.

A focus on mobility and infrastructure with little concern for energy use, as identified within transport policy, could lead to increased transport and thus higher GHG emissions. A focus on energy supply with little concern for its use (which depends on infrastructure), as identified within energy policy, could also lead to increased transport and thus higher GHG emissions. The lack of integration between transport and energy policy sectors can thus be considered an obstacle to reducing GHG emissions from transport. Integration between transport and energy policy, 
including recognition of how infrastructure and fuels can be planned jointly, could have led to effective policy measures to reduce GHG emissions from transport. In other words, widening the system boundaries to encompass both energy and transport could have benefitted sustainable development. Paper I draws the conclusion that when the energy policy sector and the transport policy sector draw separate system boundaries that only partially overlap, reductions of GHG emissions from Stockholm's transport system are hindered.

Paper II explores the question of why the production of biogas as a vehicle fuel was popular on Stockholm's political agenda. Different reasons were found. First, a gap existed between biogas supply and demand, which needed to be filled. The demand for upgraded biogas meant that sewage treatment plants profited from using municipal organic waste in the anaerobic digestion process. Other influential actors promoted biogas production for environmental reasons, in part because it turned troublesome municipal waste into an environmentally sound solution for public transport. The interview respondents were aware of the gap between biogas supply and demand, and suggested that the demand could be reduced by limiting biogas supply to public transport.

In some ways, the respondents gave the impression of applying wide system boundaries, as they reasoned around biogas as a waste management solution and around its distribution in the local transport system. However, the gap between biogas supply and demand led to the use of natural gas, resulting in a partial loss of the environmental benefits of biogas use. In addition, respondents did not discuss the use of municipal waste in existing and planned CHP plants, or the possibility of reducing food waste, and how that could affect the system. Furthermore, they viewed biogas as an interim solution even though it was highly prioritised. Thus, Stockholm's longterm planning policy can be questioned.

In summary, paper II shows that the system boundaries used in Stockholm's policy regarding biogas were basically drawn around biogas as a vehicle fuel, leaving out most aspects of waste management and alternatives to biogas. This choice of system boundaries has already led to increased use of natural gas as a vehicle fuel, even though the intention was to increase the use of biogas. There is also a risk that this policy may encourage food waste, as such waste can be turned into a popular vehicle fuel. Assuming that increased resource use is considered unsustainable, a conclusion from paper II is that narrow system boundaries could hinder the sustainable development of the transport and energy systems in Stockholm. 


\section{Chapter 5}

Paper $\mathrm{V}$ explores the framing of electric vehicles in EU policy documents. The analysis suggests that electric vehicles are primarily a solution to maintaining mobility and economic growth, which could otherwise be threatened with decline due to climate goals and attempts to reduce oil dependency. Electric vehicles are presented as clean and energy-efficient innovations, and as such, appear to be assumed to help achieve climate goals. In the studied EU policy documents, the focus is on electric vehicles as technical artefacts. Their use in the transport system and the consequences of such use are not examined.

However, the climate impact of electric vehicles depends on how much they are used, in which environment they are used and when they are charged. The quantity of GHG emissions associated with electric-vehicle use depends on how the electricity system is affected by electric-vehicle charging. A positive image of electric vehicles could lead to extended use, with electric vehicles replacing not only other automobiles but also public transport and cycling. In this situation, not only fossil fuels would be replaced by electricity; so would lower-emission alternatives. Paper V concludes that unless the use of electric vehicles is recognised in policy, electric vehicles are unlikely to contribute significantly to sustainable road transport. Thus, the system boundary used in the studied policy documents - a boundary that is drawn tightly around the electric vehicle - is assumed to hinder sustainable development of the transport system. Paper $\mathrm{V}$ argues that including the electricity system and the users of electric vehicles in the system will facilitate GHG-emission reductions.

\subsubsection{System development: Findings from paper III}

Paper III applies concepts from large technical systems theory to explain how biogas production and use have evolved in Sweden, and what factors have affected this development. For decades, biogas was produced as a by-product of waste management, such as sewage treatment. The use of biogas as fuel, mainly in heating, was a sideeffect. However, technological style changed over time. In the 1990s, the idea of producing biogas from municipal waste and using it as a fuel in urban public transport became popular as a means to reduce local air pollution. Since this shift in technological style, opportunities to use biogas as a vehicle fuel in order to reduce GHG emissions have gained increasing political interest.

Paper III argues that a one-sided focus on biogas as a vehicle fuel does not significantly increase biogas production. Raw biogas is being upgraded to natural-gas quality to a greater extent, and the number of biogas-fuelled vehicles is increasing, but the actual production of raw biogas is increasing quite slowly. Paper III observes that biogas is viewed as a kind of nation-wide system, with the sole objective of reducing 
GHG emissions from road transport through the use of biogas as a vehicle fuel. This paper concludes that there is no single biogas system, but rather a multitude of systems, each with its own technological style and its own objectives. The aspect of biogas production as a waste-management solution should not be forgotten, as it lies behind a large share of biogas production. In order to encourage the development of biogas production, policy should support the multitude of biogas systems. This support cannot be achieved by applying a system boundary that only includes upgrading and biogas vehicles. The system boundary applied by policy-makers should include all the objectives, problems and solutions that relate to biogas but that are more or less visible in different sectors, such as waste management. Thus, biogas could contribute more to GHG-emission reductions from energy and transport systems.

\subsubsection{System boundaries as prerequisites for sustainable development}

It cannot be said that policy-makers consciously apply system boundaries in the same sense as theorists apply them in energy systems research, as exemplified in section 5.1. Yet system boundaries are drawn within policy, and as seen in papers I, II and $\mathrm{V}$, these boundaries are often drawn rather tightly around an issue or a technology. Paper I shows how policy sectors can be concerned with the same issue, GHG emissions from transport, but still work with only partially overlapping systems. Paper II shows how municipal organic waste can be viewed in a biogas production system, while other resource-use issues are left outside the system boundary. Paper V shows how policy can draw a system boundary around a specific technology, electric vehicles, but leave out the use of this technology. Paper III calls for wide system boundaries in policy, in order to encourage substantial increases in biogas production so that it can contribute more to sustainable energy and transport systems. A common conclusion from papers I, II, III and V is that narrow system boundaries can hinder sustainable development in energy and transport systems.

Every attempt to solve a wicked problem has consequences that modify the problem (Fast and McCormick, 2012; Rittel and Webber, 1973). This section shows that with the narrow system boundaries in energy and transport policy, policy measures that are promoted as and/or perceived as sustainable development could in fact create additional problems that need solutions. The complexity of the wicked problem of reducing GHG emissions from energy and transport systems could thus be increased. Approaches to this wicked problem could be helped by wider system boundaries, as the consequences and effects of policy actions would then be more clearly visible. Unwanted effects such as the use of natural gas instead of biogas, or 


\section{Chapter 5}

the use of electric vehicles instead of public transport, could be discovered before becoming part of the problem.

\subsection{Research question III: How can a sociotechnical systems approach bene- fit studies of GHG-emission reductions from energy and transport systems?}

A sociotechnical approach is used throughout the thesis and in the appended papers. This takes different shapes in the different papers, but in general the sociotechnical approach functions as a framework for the studies. In papers I, II and V, the sociotechnical approach forms the foundation for a combination of methods, where one method is used to study policy and another is used to study technical conditions. By analysing the findings jointly, the intention of papers I, II and V is to identify implications for future development of the studied systems. In paper III, the sociotechnical analysis revolves around two concepts from the theory of large technical systems, which was specifically developed for analysing society and technology as intertwined. In papers IV and VI, the sociotechnical approach is not actively used but rather works as background and motivation for the studies. Although these two papers focus on the technical assessment of GHG emissions, an underlying assumption is that the GHG emissions are not a result of technology alone but of a sociotechnical system. The intention of papers III, IV and VI is to identify implications for the future development of the studied sociotechnical systems. This section analyses and discusses the different ways of using a sociotechnical systems approach in the studies that the thesis comprises.

\subsection{The combination of methods in papers I, II and V}

In a paper outlining methods for scenario studies, Banister and Hickman (2013: p. 292) identify an implementation gap between research and policy for sustainable transport: "The current research investigates and brings new understanding to the problem (e.g. sustainability in transport), but the means by which that knowledge is then translated into policy measures is weak." They suggest ways to improve the usefulness of scenario studies, such as developing more realistic backcasting scenarios (Banister and Hickman, 2013). While the point of backcasting is to visualise pathways to desired future scenarios, which are often radically different from the current situation, actually embarking on these pathways takes considerable effort. Showing what is required is easier than doing what is required. In order to facilitate policy measures directed at reaching a desired future scenario, it might help to aim for a future that is not so radically different. 
The usefulness of backcasting studies forms the background of paper I, in which backcasting is combined with policy integration analysis. Two desired future scenarios are constructed, based on the technical feasibility of biofuels and electric vehicles. Policy measures are required in order to reach these future scenarios. To understand the feasibility of such policy measures, the policy process in the energy and transport policy sectors was studied with respect to policy integration, as discussed in section 5.2. Paper I concludes that this combination of methods is useful, as it provides understanding into the difficulties of implementing backcasting research. By using policy integration analysis as an input to backcasting, scenarios can be constructed based not only on technical feasibility, but also on their rootedness in the policy process. Thus, the realisation of backcasting studies could be improved.

Paper II, which is discussed in sections 5.1 and 5.2, combines interviews with actors involved in the regional policy process with a GHG-emission assessment of using municipal organic waste to produce biogas for use as a vehicle fuel. The reason for this combination is to gain an understanding of the consequences of both political decisions and technical implementations. The GHG-emission assessment includes different options for the use of municipal organic waste and biogas. The interviews show that alternatives were not discussed in the policy process; the focus was exclusively on turning municipal organic waste into vehicle fuel, primarily for use in public transport. This combination of methods and their different findings allow for a discussion about different options and their implications for future energy and transport systems.

In Paper V, two methods are used to study the introduction of electric vehicles in the EU. This paper explores the consequences of using different system boundaries in a sociotechnical systems approach to analysing the climate impact of electric vehicles. In addition, the reasons for introducing electric vehicles are explored in an analysis of policy framing, as discussed in section 5.2. As in paper II, the combination of methods is an attempt to illuminate different aspects of the issue, and thus gain an understanding of the complexities with regard to sustainable development. By combining two methods, it is possible to problematise the reasons behind the electric-vehicle introduction and show that this introduction could have a negative impact on the sustainability of the transport system. Also, the two methods make it possible to suggest how electric-vehicle policy might be developed in order to contribute more to reducing GHG emissions from the transport system. 


\section{Chapter 5}

\subsubsection{The sociotechnical systems approach as used in papers III, IV and VI}

In paper III, biogas production and use is studied using two concepts from large technical systems theory; technology transfer and technological style. As a whole, large technical systems theory describes system development as a process where technology shapes society and society constructs technology. The specific concepts, as described in section 4.2.3, symbolise technology in different contexts; how different social settings affect technology. In paper III, this is useful for explaining the ongoing development of biogas production and use, a process that has many different features depending on its social context.

In papers IV and VI, the sociotechnical approach is not as visible. There, the focus is on GHG emissions given different system boundaries, the effects of which are shown in purely technical terms. Yet, an underlying assumption is that the studied systems are sociotechnical. In paper IV, GHG emissions from electric vehicles are analysed in a context where there is a choice of vehicles and electricity production processes; technological choices which of course are influenced by policy. In paper VI the underlying sociotechnical framework is a little more visible, with the choice between different heat supply alternatives shown not just to be a choice between two technologies but a choice affected by several social and economic factors.

\subsubsection{Using different approaches and methods to understand sociotechnical systems}

A sociotechnical approach is applied throughout this thesis, albeit differently in each of the appended papers. Viewing a technology as inherently integrated with society, as in paper III, is shown to be a good way of analysing system development. It shows how technical development, policy-makers, producers and consumers interact and what consequences that different actions have had on the development. By gaining a greater understanding of consequences, GHG emission reductions can be facilitated. Using a sociotechnical approach as an underlying framework, as in paper IV and VI, is proven to be an interesting point of departure for problematising assumptions and results, even when a sociotechnical approach is not explicitly used in the analysis. Society affects technology; thus it affects the study and the system boundaries. The sociotechnical framework enables problematisation.

The use of different methods and approaches allows the issue of GHG emission reductions from energy and transport systems to be illuminated from different angles. Complex relationships can be identified and examined, the use of different system boundaries can be studied, implications for the future can be discussed, and 
possible improvements can be suggested. Thus, a greater understanding of GHG emission reductions from energy and transport systems can be achieved than if a single method had been used in the thesis and if the analytical framework had been the same in all the appended papers.

The specific combination of methods, where some are used to study policy and others to study technical conditions, also contributes to a deeper understanding of the research area. Methods that yield numerical results are often viewed as more accurate and less biased than interpretations of texts and interviews (Lélé and Norgaard, 2005). A calculation must be done according to a defined method, and regardless of who performs the calculation, the outcome is the same, provided that it is correctly done. Analyses of documents and interviews are of course also based on defined methodologies, but as both the methods and the texts are open for interpretation by the researcher, the outcome may differ depending on who performs the analysis. GHG-emission assessments also have a layer of interpretation. However, the possibility of bias is more often accounted for in text analyses than in GHG-emission calculations (Lélé and Norgaard, 2005). Using a combination of methods may increase reflections on methodology and its impact on research and results. If one method requires reflection on how it is realised, it seems likely that all methods require similar reflection. Such reflection could increase understanding of the wicked problem of GHG-emission reductions from energy and transport systems, as it would show how the problem becomes more complex instead of being solved by imperfect solutions. As discussed in sections 5.1 and 5.2, attempts to solve a wicked problem can result in modifications to the problem or in new problems that require new solutions. Thus, the use of methodology without reflection in attempts to solve wicked problems could have dire consequences.

Paper I offers suggestions for methodological improvement. Backcasting studies could become more useful and more likely to contribute to reducing GHG emissions from energy and transport systems, if the recipe in paper I is followed. Combining backcasting and policy analysis is a concept based on a pragmatic regard of what can be achieved. In paper I, it is considered that a minor achievement is preferable to failure to achieve a highly set goal. In this case, the limitations are political rather than technical. The technical prerequisites to reach the desired future scenarios have already been identified as existing; it is the political prerequisites that are lacking. This is one of the characteristics of a wicked problem: that it is a matter of policy and planning, rather than a technical issue (Fast and McCormick, 2012; Rittel and Webber, 1973). By using a combination of methods, paper I helps to display the wicked problem of reducing GHG emissions from energy and transport systems, 


\section{Chapter 5}

and clearly shows that the core of the problem lies within policy. This example shows how combining methods helps to demonstrate that the reduction of GHG emissions from energy and transport systems is problematic.

In this thesis, the sociotechnical approach is exemplified in all the appended papers and in the synthesis of the papers. Combinations of methods and analytical frameworks are applied both in individual papers and in the thesis as a whole. The benefits of illuminating different aspects of an issue by viewing it from different angles and using different tools is discussed. The sociotechnical systems approach is shown useful for the study of the wicked problem of reducing GHG emissions from energy and transport systems. 


\section{Concluding remarks}

\section{I Conclusions}

The aim of this thesis is to show how GHG-emission reductions from energy and transport systems can be understood, approached and studied as a wicked problem. This aim is addressed by three research questions, each of which has led to a conclusion.

Research question I: How does the choice of system boundaries affect the results of energy system research?

Conclusion: The choice of system boundaries matters, and that choice should depend on the system under study. GHG-emission assessments can give very different results depending on system boundaries, and these results can significantly complicate the wicked problem of reducing GHG emissions from energy systems. Therefore, system boundaries should be chosen carefully.

Research question II: How do the system boundaries used in energy and transport policy affect the sustainable development of energy and transport systems?

Conclusion: Narrow system boundaries in energy and transport policy can hinder reductions of GHG emissions from energy and transport systems. Wider system boundaries can make consequences and effects of policy actions more clearly visible, thus facilitating approaches to solve the wicked problem of reducing GHG emissions from energy and transport systems, which is inherently a policy problem.

Research question III: How can a sociotechnical systems approach benefit studies of GHG-emission reductions from energy and transport systems?

Conclusion: A sociotechnical approach can be useful as a platform for problematising issues, thus illuminating complexities of a wicked problem. Combining different 


\section{Chapter 6}

methods can illuminate different aspects of an issue, thus adding to the understanding of that issue and of its characteristics as a wicked problem. Therefore, it is useful to combine different methods when studying GHG-emission reductions from energy and transport systems, since this issue encompasses several technical and policyrelated issues, and has been explained as a wicked problem.

This thesis shows how the reduction of GHG emissions from energy and transport systems can be understood as a wicked problem by explaining how attempts at solutions can increase the complexity of the problem and modify it so that new solutions are required. The "wickedness" is revealed by problematising the handling of the reduction of GHG emissions from energy and transport systems within energy systems research and within energy and transport policy, using a sociotechnical approach. It is suggested that approaches to contribute to solving this wicked problem should include transparency, carefully chosen system boundaries and awareness of consequences of different actions. Awareness that the reduction of GHG emissions from energy and transport systems is a wicked problem, and thus is not easily solved - and moreover, that attempts at solutions can add to the complexity of the wicked problem - can be a useful point of departure for research and policy.

\subsection{Contribution to the research field}

This thesis studies GHG-emission reductions from energy and transport systems as a wicked problem. It contributes to energy and transport systems research by explaining how attempts to reduce GHG emissions can create additional similar problems that also need solutions, since inadequate solutions simply add to the "wickedness" of the problem. This thesis also points out the importance of understanding policy, as the solutions to wicked problems are mainly found in policy rather than in technology.

This thesis shows how a sociotechnical approach to energy systems analysis can offer insights on how system boundaries are handled within energy systems research and within energy and transport policy. It also shows how a combination of methods within a sociotechnical systems framework can contribute to a greater understanding of the system under study. In these ways, it contributes to the field of sociotechnical system studies of energy and transport systems.

\subsection{Further work}

Sociotechnical systems are complex. In order for the complexity of GHG emission reductions in energy and transport systems to be better understood, additional stud- 
ies of this issue would be beneficial. In this thesis, the issue is approached broadly. While this has the benefit of illuminating a wide range of complexities, a more limited but deeper approach could be useful for further problematising the issue and identifying the roots of the wicked problem. Studying the issue in other settings than a Swedish/European one could also be beneficial, as the relevance of the sociotechnical context means that a wicked problem has different characteristics in different contexts.

The implementation of measures to reduce GHG emissions from energy and transport systems is an interesting topic. Studies of how and why measures are implemented, and evaluations of the implementation, could contribute to the understanding of the wicked problem and its persistence. These suggestions for further research include research that is already being undertaken. However, connecting that research to the approach of GHG emission reductions from energy and transport systems as a wicked problem could add usefulness and provide further insights. 


\section{References}

Anable J, Brand C, Tran M, Eyre N, 2012. Modelling transport energy demand: A socio-technical approach. Energy Policy 41:125-138.

Axelsson E, Harvey S, Berntsson T, 2009. A tool for creating energy market scenarios for evaluations of investments in energy intensive industry. Energy 34:2069-2074.

Bacchi CL, 2008. Women, policy and politics: The construction of policy problems. Sage, London.

Bale CSE, Varga L, Foxon TJ, 2015. Energy and complexity : New ways forward. Applied Energy 138:150-159.

Banister D, Hickman R, 2013. Transport futures: Thinking the unthinkable. Transport Policy 29:283-293.

Berglund M, 2006. Biogas production from a systems analytical perspective. $\mathrm{PhD}$ thesis in Environmental and Energy Systems Studies, Lund University.

Bijker WE, 2013. Social construction of technology. In: Olsen JKB, Pedersen SA, Hendricks VF (Eds.), A companion to the philosophy of technology. Blackwell Publishing Ltd, Malden, MA, pp. 88-94.

Bolton R, Foxon TJ, 2015. A socio-technical perspective on low carbon investment challenges - Insight for UK energy policy. Environmental Innovation and Societal Transitions 14:165-181.

Borrion AL, McManus MC, Hammond GP, 2012. Environmental life cycle assessment of lignocellulosic conversion to ethanol: A review. Renewable and Sustainable Energy Reviews 16:4638-4650.

Boulding K, 1956. General systems theory - the skeleton of science. Management Science 2:197-208.

Broberg Viklund S, Johansson MT, 2014. Technologies for utilization of industrial excess heat: Potentials for energy recovery and $\mathrm{CO}_{2}$ emission reduction. Energy Conversion and Management 77:369-379.

Börjesson P, 2009. Good or bad bioethanol from a greenhouse gas perspective What determines this? Applied Energy 86:589-594.

Chertow MR, 2000. Industrial symbiosis: Literature and taxonomy. Annual Review of Energy and the Environment 25:313-337. 
Chester L, 2010. Conceptualising energy security and making explicit its polysemic nature. Energy Policy 38:887-895.

Chong D, Druckman JN, 2007. Framing theory. Annual Review of Political Science 10:103-26.

Churchman CW, 1968. The systems approach. Delacorte Press, New York.

Collins H, 2013. Social construction of science. In: Olsen JKB, Pedersen SA, Hendricks VF (Eds.), A companion to the philosophy of technology. Blackwell Publishing Ltd, Malden, MA, pp. 84-87.

Connolly D, Lund H, Mathiesen BV, Werner S, Möller B, Persson U, Boermans T, Trier D, Östergaard PA, Nielsen S, 2014. Heat Roadmap Europe: Combining district heating with heat savings to decarbonise the EU energy system. Energy Policy 65:475-489.

Difs K, 2010. National energy policies: Obstructing the reduction of global $\mathrm{CO}_{2}$ emissions? An analysis of Swedish energy policies for the district heating sector. Energy Policy 38:7775-7782.

Difs K, Wetterlund E, Trygg L. Söderström M, 2010. Biomass gasification opportunities in a district heating system. Biomass and Bioenergy 34:637-651.

Djuric Ilic D, Dotzauer E, Trygg L, Broman G, 2014. Introduction of large-scale biofuel production in a district heating system - an opportunity for reduction of global greenhouse gas emissions. Journal of Cleaner Production 64:552-561.

Djuric Ilic D, Trygg L, 2014. Economic and environmental benefits of converting industrial processes to district heating. Energy Conversion and Management 87:305317.

Dotzauer E, 2010. Greenhouse gas emissions from power generation and consumption in a Nordic perspective. Energy Policy 38:701-704.

Dreborg KH, 1996. Essence of backcasting. Futures 28:813-828.

EC (European Commission), 2014. EU energy, transport and GHG emissions trends to 2050. doi: 10.2833/17897.

Ekener-Petersen E, Höglund, J, Finnveden G, 2014. Screening potential social impacts of fossil fuels and biofuels for vehicles. Energy Policy 73:416-426. 
Ekvall T, Tillman A-M, Molander A, 2005. Normative ethics and methodology for life cycle asessment. Journal of Cleaner Production 13:1225-1234.

Fallde M, 2011. Miljö i tanken? Policyprocesser vid övergången till alternativa drivmedel i kollektivtrafiken i Linköping och Helsingborg 1976-2005. Linköping Studies in Arts and Science No. 534, Linköping University. In Swedish.

Fargione J, Hill J, Tilman D, Polasky S, Hawthorne P, 2008. Land clearing and the biofuel carbon debt. Science 319, 1235-1238.

Fast S, McCormick K, 2012. Biofuels: from a win-win solution to a wicked problem? Biofuels 3:737-748.

Finnveden, $\mathrm{G}, 2008$. A world with $\mathrm{CO}_{2}$ caps: Electricity production in consequential assessments. International Journal of Life Cycle Assessment 13:365-367.

Geels F, 2004. From sectoral systems of innovation to socio-technical systems. Insights about dynamics and change from sociology and institutional theory. Research Policy 33:897-920.

Geerlings H, Stead D, 2003. The integration of land use planning, transport and environment in European policy and research. Transport Policy 10:187-196.

Girod B, van Vuuren DP, Grahn M, Kitous A, Kim SH, Kyle P, 2013. Climate impact of transportation. A model comparison. Climatic Change 118:595-608.

Grahn M, Azar C, Williander MI, Anderson JE, Mueller SA, Wallington TJ, 2009. Fuel and vehicle technology choices for passenger vehicles in achieving stringent $\mathrm{CO}_{2}$ targets: Connections between transportation and other energy sectors. Environmental Science and Technology 43:3365-3371.

Grahn P, Alvehag K, Söder L, 2012. Plug-in vehicle mobility and charging flexibility Markov model based on driving behaviour. In Proceedings of the 9th International Conference on the European Energy Market, 2012.

Grahn P, Munkhammar J, Widén J, Alvehag K, Söder L, 2013. PHEV homecharging model based on residential activity patterns. IEEE Transactions on Power Systems 28:2507-2515.

Hatzopoulou M, Miller EJ, 2008. Institutional integration for sustainable transportation policy in Canada. Transport Policy 15:149-162. 
Henning D, Trygg L, 2008. Reduction of electricity use in Swedish industry and its impact on national power supply and European $\mathrm{CO}_{2}$ emissions. Energy Policy $36: 2330-2350$.

Holden E, Linnerud K, Banister D, 2014. Sustainable development: Our common future revisited. Global Environmental Change 26:130-139.

Hughes TP, 1983. Networks of power: Electrification in Western society 1880-1930. Johns Hopkins University Press, Baltimore.

Höjer M, Mattsson LG, 2000. Determinism and backcasting in future studies. Futures 32:613-634.

Ingelstam L, 2012. System - att tänka över samhälle och teknik. Energimyndigheten, Eskilstuna, Sweden. In Swedish.

IPCC (Intergovernmental Panel on Climate Change), 2014. Climate change 2014: Synthesis report. Available at www.ipcc.ch/publications_and_data/publications_ and_data_reports.shtml, 2015-02-22.

Jacobsson S, Karltorp K, 2013. Mechanisms blocking the dynamics of the European offshore wind energy innovation system - Challenges for policy intervention. Energy Policy 63:1182-1195.

Karlsson M, Wolf A, 2008. Using an optimization model to evaluate the economic benefits of industrial symbiosis in the forest industry. Journal of Cleaner Production $16: 1536-1544$.

Keirstead J, Jennings M, Sivakumar A, 2012. A review of urban energy system models: Approaches, challenges and opportunities. Renewable and Sustainable Energy Reviews 16:3847-3866.

Klessman C, Held A, Rathmann M, Raqwitz M, 2011. Status and perspectives of renewable energy policy and deployment in the European Union - What is needed to reach the 2020 targets? Energy Policy 39:7637-7657.

Latour B, 1987. Science in action. Harvard University Press, Cambridge MA.

Leduc S, Lundgren J, Franklin O, Dotzauer E, 2010a. Location of a biomass based methanol production plant: A dynamic problem in northern Sweden. Applied Energy 87:68-75. 
Leduc S, Starfelt F, Dotzauer E, Kindermann G, McCallum I, Obersteiner M, Lundgren J, 2010b. Optimal location of lignocellulosic ethanol refineries with polygeneration in Sweden. Energy 35:2709-2716.

Lélé S, Norgaard RB, 2005. Practising interdisciplinarity. BioScience 55:967-975.

Lindfeldt EG, Saxe M, Magnusson M, Mohseni F, 2010. Strategies for a road transport system based on renewable resources -The case of an import-independent Sweden in 2025. Applied Energy 87:1836-1845.

Lise W, van der Laan J, Niuwenhout F, Rademaekers K, 2013. Assessment of the required share for a stable EU electricity supply until 2050. Energy Policy 59:904913.

Lund H, Werner S, Wiltshire R, Svendsen S, Thorsen JE, Hvelplund F, Mathiesen BV, 2014. 4th Generation District Heating (4GDH). Integrating smart thermal grids into future sustainable energy systems. Energy 68:1-11.

Lybæk R, Budde Christensen T, Kjær T, 2013. Governing innovation for sustainable development in the Danish biogas sector - a historical overview and analysis of innovation. Sustainable Development 21:171-182.

Magnusson D, 2012a. Swedish district heating - A system in stagnation: Current and future trends in the district heating sector. Energy Policy 48:449-459.

Magnusson M, 2012b. Energy system studies of biogas: Generation aspects of renewable vehicle fuels in the transport system. $\mathrm{PhD}$ thesis in Chemical Science and Engineering, KTH Royal Institute of Technology.

Marsden G, Ferreira A, Bache I, Flinders M, Bartle I, 2014. Muddling through with climate change: a multi-level governance perspective on the transport sector. Climate Policy 14:617-636.

Martin M, Eklund M, 2011. Improving the environmental performance of biofuels with industrial symbiosis. Biomass and Bioenergy 35:1747-1755.

Martin M, Svensson N, Fonseca J, Eklund M, 2014. Quantifying the environmental performance of integrated bioethanol and biogas production. Renewable Energy 61:109-116.

Moezzi M, Janda KB, 2014. From "if only" to "social potential" in schemes to reduce building energy use. Energy Research \& Social Science 1:30-40. 
Mohseni F, Magnusson M, Görling M Alvfors P, 2012. Biogas from renewable electricity - Increasing a climate neutral fuel supply. Applied Energy 90:11-16.

Möst D, Fichtner W, 2010. Renewable energy sources in European energy supply and interactions with emission trading. Energy Policy 38:2898-2910.

Nykvist B, Nilsson M, 2014. The EV paradox - A multilevel study of why Stockholm is not a leader in electric vehicles. Environmental Innovation and Societal Transitions, In Press.

Odenberger M, Unger T, Johnsson F, 2009. Pathways for the North European electricity supply. Energy Policy 37:1660-1677.

Palm J, 2013. The building process of single-family houses and the embeddedness (or disembeddedness) of energy. Energy Policy 62:762-767.

Palm J, Thollander P, 2010. An interdisciplinary perspective on industrial energy efficiency. Applied Energy 87:3255-3261.

Peoples C, 2014. New nuclear, new security? Framing security in the policy case for new nuclear power in the United Kingdom. Security Dialogue 45:156-173.

Persson U, Werner S, 2012. District heating in sequential energy supply. Applied Energy 95:123-131.

Radder H, 2013. Science and technology: Positivism and critique. In: Olsen JKB, Pedersen SA, Hendricks VF (Eds.), A companion to the philosophy of technology. Blackwell Publishing Ltd, Malden, MA, pp. 61-65.

Rezaie B, Rosen MA, 2012. District heating and cooling: Review of technology and potential enhancements. Energy 93:2-10.

Rittel HWJ, Webber MM, 1973. Dilemmas in a general theory of planning. Policy Sciences 4:155-169.

Robinson JB, 1990. Futures under glass: A recipe for people who hate to predict. Futures 22:820-842.

Rouillard JJ, Heal KV, Ball T, Reeves AD, 2013. Policy integration for adaptive water governance: Learning from Scotland's experience. Environmental Science and Policy 33:378-387.

Ryckebosch E, Drouillon M, Vervaeren H, 2011. Techniques for transformation of biogas to biomethane. Biomass and Bioenergy 35:1622-1645. 
SEA (Swedish Energy Agency), 2014. Energy in Sweden 2014 - facts and figures. Available at http://www.energimyndigheten.se/Press/Nyheter/En-samlad-bild-overenergilaget-i-Sverige/ 2015-01-08.

Searchinger T, Heimlich R, Houghton RA, Dong F, Elobeid A, Fabiosa J, Tokgoz S, Hayes D, Yu T-H, 2008. Use of U.S. croplands for biofuels increases greenhouse gases through emissions from land-use change. Science 319:1238-1240.

SEMI (Swedish Energy Markets Inspectorate), 2014. Import och export av el. In Swedish. Available at http://www.ei.se/sv/Publikationer/fakta-informationsmaterial /faktablad/import-och-export-av-el/ 2015-03-09.

Sjödin J, Grönkvist S, 2004. Emissions accounting for use and supply of electricity in the Nordic market. Energy Policy 32:1555-1564.

Sokka L, Lehtoranta S, Nissinen A, Melanen M, 2011. Analyzing the environmental benefits of industrial symbiosis. Life cycle assessment applied to a Finnish forest industry complex. Journal of Industrial Ecology 15:137-155.

Summerton J (Ed.), 1994. Changing Large Technical Systems. Westview Press, Boulder/San Francisco/Oxford.

Söderberg C, 2011. Institutional conditions for multi-sector environmental policy integration in Swedish bioenergy policy. Environmental Politics 20:528-546.

Tie SF, Tan CW, 2013. A review of energy sources and energy management system in electric vehicles. Renewable and Sustainable Energy Reviews 20:82-102.

Tran M, 2014. Modeling sustainability transitions on complex networks. Complexity 19:8-22.

van der Vleuten E, 2009. Large technical systems. In: Olsen JKB, Pedersen SA, Hendricks VF (Eds.), Blackwell companion to the philosophy of technology. WileyBlackwell, Malden, MA, pp. 218-223.

van Vliet O, Sjouerd Brouwer A, Kuramochi T, van den Broek M, Faaij A, 2011. Energy use, cost and $\mathrm{CO}_{2}$ emissions of electric cars. Journal of Power Sources $196: 2298-2310$

Wetterlund E, Pettersson K, Magnusson M, 2010. Implications of system expansion for the assessment of well-to-wheel $\mathrm{CO}_{2}$ emissions from biomass-based transportation. International Journal of Energy Research 34:1136-1154. 
WRI (World Resources Institute), 2007. Guidelines for quantifying GHG reductions from grid-connected electricity projects. Available at http://www.ghgprotocol. org/standards 2015-01-08.

Åhman M, 2010. Biomethane in the transport sector - An appraisal of the forgotten option. Energy Policy 38:208-217. 


\section{Papers}

The articles associated with this thesis have been removed for copyright reasons. For more details about these see:

http://urn.kb.se/resolve?urn=urn:nbn:se:liu:diva-116685 